\title{
PERANCANGAN SISTEM MANAJEMEN KEAMANAN INFORMASI LAYANAN PENGADAAN BARANG/JASA SECARA ELEKTRONIK (LPSE) DI DINAS KOMUNIKASI DAN INFORMATIKA KABUPATEN CIANJUR DENGAN MENGGUNAKAN SNI ISO/IEC 27001:2013
}

\author{
Fuad Nasher \\ Program Studi Teknik Informatika \\ Univeristas Suryakancana \\ Fuad.nasher@gmail.com
}

\begin{abstract}
LPSE Unit (Electronic Procurement Service) in Cianjur District is an e-procurement application with Embedded IT system concept that performs its function as a virtual market that brings together goods / service providers and those who need goods / services, in order to realize clean and good government in procurement goods / services Government. Infrastructure in LPSE unit is still a major obstacle in the implementation of information security incidents that often resulted in disruption of business processes due to lack of awareness of the importance of Information Security. With the establishment of the ISMS, information can be properly managed, ensuring business continuity, minimizing risks, limiting the impact of security breaches and safeguarding aspects of confidentiality, integrity, and availability of information. The design of the ISMS in this study refers to SNI ISO / IEC 27001: 2013 and SNI ISO / IEC 27005: 2013 standards. In the design of the ISMS, there are several stages of identifying information assets, threats, vulnerabilities, risks, impacts, and evaluating (Questionnaire) levels of availability based on the selected clauses. This research produces document design process of ISMS in the form of design of Information Security Manual Document, Work Procedure and Working Form.
\end{abstract}

Keywords: LPSE, ISMS, E-Procurement, Security, Aset, Risk

\begin{abstract}
Abstrak
Unit LPSE (Layanan Pengadaan Secara Elektronik) Kabupaten Cianjur merupakan aplikasi e-procurement dengan konsep Embedded IT system yang menjalankan fungsinya sebagai pasar virtual yang mempertemukan penyedia barang/jasa dan pihak yang membutuhkan barang/jasa, dengan tujuan guna mewujudkan clean and good government dalam pengadaan barang/jasa Pemerintah. Infrastruktur TI Unit LPSE ini masih menjadi kendala besar dalam pelaksanaanya yaitu sering terjadi insiden keamanan informasi yang mengakibatkan terganggunya proses bisnis dikarenakan kurangnya kesadaran akan pentingnya Keamanan Informasi. Dengan dibangunya SMKI, agar informasi dapat dikelola dengan benar, menjamin kelangsungan bisnis, meminimalisir risiko, membatasi dampak dari pelanggaran keamanan dan menjaga aspek Kerahasiaan (confidentiality), keutuhan (Integrity), dan ketersediaan (availability) dari informasi. Perancangan SMKI yang disusun pada penelitian ini mengacu pada standar SNI ISO/IEC 27001: 2013 dan SNI ISO/IEC 27005: 2013. Dalam perancangan SMKI terdapat beberapa tahap yaitu melakukan identifikasi aset informasi, ancaman, kerentanan, risiko, dampak, dan mengevaluasi (Kuesioner) tingkat ketersediaan berdasarkan kalusul yang dipilh. Sehingga penelitian ini menghasilkan dokumen proses perancangan SMKI yaitu perancangan Dokumen Manual Keamann Informasi, Prosedur Kerja dan Formulir Kerja.
\end{abstract}

Kata kunci: LPSE, SMKI, e-procurement, Keamanan, aset, risiko

\section{Pendahuluan}

\subsection{Latar Belakang Masalah}

Perkembangan Teknologi informasi (TI) saat ini sudah menjadi kebutuhan yang sangat penting bagi hampir semua organisasi perusahaan baik instansi pemerintahan maupun swasta sebagai penunjang dalam meningkatkan evektifitas dan efesiensi proses kinerja. Pengelolaan yang baik diperlukan karena didalam teknologi informasi terdapat informasi yang merupakan aset yang sangat bernilai. Jika hal tersebut terjadi insiden maka pengaruhnya akan signifikan terhadap keberlangsungan bisnis dan kerugian materil di Perusahaan.

Salah satu upaya untuk menghadapi tantangan di era globalisasi ini organisasi harus siap menghadapi sejumlah ancaman baik itu ancaman terencana atau ancaman yang tidak bisa diprediksi. Dengan hal tersebut salah satu cara melindungi informasi didalam organisasi yaitu melalui peranan Teknologi informasi dapat meningkatkan keamanan informasi bahkan yang lebih diperlukan adalah manajemen keamanan yang berperan dalam mengamankan Informasi dan aset-aset penting dalam organisasi 
Dinas Kominfo Kabupaten Cianjur merupakan instansi Pemerintah yang bertugas menyelenggarakan urusan bidang komunikasi dan Informatika. Dalam penyelenggaran dan penerapan manajemen TIK Dinas Kominfo Cianjur sudah berjalan dengan pemanfaatan teknologi informasi karena merupakan sebuah tuntutan dan peran yang semakin penting sebagai salah satu realisasi dari lembaga Pemerintahan yang baik. Salah satunya Unit kerja penyelenggaraan pelayanan LPSE (Layanan Pengadaan Secara Elektronik). LPSE menjalankan fungsi sebagai pasar virtual yang mempertemukan penyedia barang/jasa dan pihak yang membutuhkan barang/jasa.

LPSE merupakan unit pelaksana yang memfasilitasi unit layanan pengadaan (ULP) Pejabat pengadaan pada proses pengadaan barang/jasa secara elektronik dimana tujuannya dalam rangka untuk percepatan pelaksanaan pembangunan infarstruktur daerah itu sendiri. Sistem informasi untuk LPSE ini disimpan dalam sebuah server SPSE secara mandiri (khusus) tidak ada unit-unit kegiatan yang lain bahkan pengelolaanya langsung dibawah pengawasan Koordinator LPSE.

Infrastruktur Teknologi Informasi LPSE Kominfo Kabupaten Cianjur masih menjadi kendala besar dalam pelaksanaanya yaitu sering terjadi insiden keamanan informasi yang mengakibatkan terganggunya proses bisnis, terjadinya kegagalan pengiriman ketika penyedia melakukan apload penawaran, Informasi melalui e-mail tidak bisa terkirim, server kadang tidak menerima transaksi dari penyedia barang/jasa, meskipun pada saat ini infrastruktur jaringan sudah terinstalasi seperti Firewall, Froxy dan mikrotik seperti layanan wifi/Hotspot. Selain itu penerapan langkah pengamanan masih bersifat reaktif tidak mengacu pada keseluruhan risiko yang ada, tidak ada komunikasi dan kewenangan yang jelas dan tanpa pengawasan, kelemahan teknis dan non teknis tidak teridentifikasi dengan baik serta pihak yang terlibat tidak menyadari tanggung jawab.

Dalam penyelenggaraan sistem manajemen TIK faktor Keamanan informasi merupakan aspek yang sangat penting pada LPSE di Kominfo Kabupaten Cianjur, sangat diperlukan mengingat jika informasi mengalami masalah yang menyangkut kerahasiaan, keutuhan dan ketersediaan. Terutama bahwa data-data di LPSE banyak yang merupakan data-data rahasia yang harus diamankan dan keamanan ini hal penting untuk diterapkan.

Upaya yang dapat dilakukan oleh Kementrian Kominfo adalah menyelenggarakan sosialisasi dan bimbingan teknis (Bimtek) Sistem Manajemen Keamanan Informasi (SMKI), hasilnya bahwa mayoritas instansi peserta belum memiliki atau sedang menyusun kerangka kerja keamanan informasi yang memenuhi standar SNI ISO/IEC 27001:2013. Beberapa instansi yang telah memiliki dokumentasi sistem manajemen keamanan informasi juga belum mengetahui apakah kerangka kerja yang mereka bangun telah memenuhi persyaratan standar SNI ISO/IEC 27001:2013

Hingga saat ini, Dinas Kominfo Kabupaten Cianjur belum mempunyai kerangka kerja keamanan informasi yang memenuhi standar SNI ISO/IEC 27001:2013. Selain itu pemerintah melalui PerMenKominfo no 4 Tahun 2016 telah mengarahkan penggunaan SNI ISO/IEC 27001:2013 untuk data-data yang penting wajib bagi penyelenggara sistem elektronik dalam penerapan Sistem Manajemen Keamanan Informasi, sehingga dalam penelitian ini penulis ingin mengangkat topik salah satu tindakan supaya tidak terjadi insiden atau ancaman yang menyebabkan gangguan Keamanan Informasi yaitu dengan menerapkan Perancangan Sistem Manjemen Keamanan Informasi SMKI, ini diharapkan dapat mengamankan aset-aset yang terdapat pada Dinas Kominfo Kabupaten Cianjur dan elemen-elemen lain yang harus benar-benar diamankan.

\subsection{Rumusan Masalah}

Berdasarkan uraian dari latar belakang diatas maka rumusan masalah yang dibuat yaitu:

1. Bagaimana cara melakukan Perancangan SMKI berbasis risiko dengan standar SNI ISO/IEC 27001: 2013 dan SNI ISO/IEC 27005 : 2013 untuk prosedur keamanan informasi

2. Bagaimana cara melakukan Manajemen Risiko Keamanan Informasi di LPSE Kominfo Kabupaten Cianjur

3. Bagaimana cara pemetaan kontrol keamanan terhadap standar SNI ISO/IEC 27001: 2013 berdasarkan hasil dari proses Manajemen Risiko keamanan Informasi

\subsection{Batasan Masalah}

Adapun batasan masalah dari pembahasan penelitian ini. Agar pembahasan tidak terlalu luas antara lain

1. Menyusun perancangan Sistem Manajemen Keamanan Informasi pada Dinas Komunikasi dan Informatika Kabupaten Cianjur menggunakan standar ISO/IEC 27001:SNI 2013 dengan tahapan Plan-docheck-act, untuk manajemen Risiko keamanan informasi menggunakan satandar SNI ISO/IEC 27005:2013

2. Rencana klausul yang digunakan adalah Anek A Klausul : A 7 Sumber Daya manusia, Klausul A8 Manajemen Aset, Klausul A9 Kontrol Akses, Klausul A 11 Keamanan Fisik dan lingkungan dan Klausul A13 Keamanan Komunikasi.

3. Perancangan SMKI yang dibangun terdiri dari perancangan Manual Keamanan Informasi, Prosedur dan Formulir keamanan informasi.

\subsection{Tujuan Penelitian}

Menghasilkan dokumen proses perancangan Sistem manajemen keamanan informasi untuk Infrastruktur TI LPSE Dinas Komunikasi dan Informatika Kabupaten Cianjur menggunakan standar SNI ISO/IEC 27001:2013 yang terdiri dari :

a. Perancaangan dokumen manual sistem manajemen keamanan Informasi

b. Perancangan Prosedur sistem manajemen keamanan Informasi

c. Perancangan Formulir

\subsection{Metode Penelitian}

Dalam melakukan penelitian ini, terdapat beberapa tahap yang akan dilakukan oleh penyusun, yaitu : 
1. Studi Literatur dan referensi baik dari buku atau sumber-sumber dari internet terkait dengan keamanan Informasi

2. Membuat Daftar Kuesioner. Daftar kuesioner ini di susun untuk semua level manajemen yang terlibat dalam sistem dengan tujuan mengumpulkan informasi seputar praktek praktek keamanan informasi dengan tujuan untuk memperoleh pemahaman organisasi tentang keamanan informasi kemudian data tersebut dianalisis

3. Melakukan Analisis terhadap objek penelitian yang didalamnya menganalisis aset, risiko dan dampak

4. Menyusun Kerangka Kerja sistem manajemen Keamanan informasi kemudian akhirnya menjadi sebuah dokumen SMKI berdasarkan hasil penelitian

5. Menyusun Kesimpulan dan saran

\section{Tinjauan Pustaka}

\subsection{Pentingnya Keamanan Informasi}

Pada era globalisasi berbagai organisasi dihadapakan dengan Sejumlah ancaman Keamanan Informasi dari berbagai sumber. Hal ini diperlihatkan sejumlah kasus kejahatan komputer secara disengaja. Seperti pencurian data, spionase, hacking atau ancaman yang diakibatkan bencana alam. Dengan demikian dari keseluruhan ancaman merupakan risiko yang dihadapi oleh organisasi bersangkutan.

Penjagaan Keamanan Informasi diperlukan usaha dalam memperhatikan faktor keamanan dan keseluruhan piranti pendukung yang terkait langsung atau tidak langsung dengan proses pengolahan Informasi. Dengan amannya keseluruhan lingkungan tempat informasi berada maka kerahasiaan, integritas, dan ketersedian Informasi akan dapat secara efektif.

Keamanan yang baik dapat dicapai diantaranya:

Penerapan sejumlah upaya teknis yang didukung oleh berbagai kebijakan dan prosedur manajemen yang sesuai, yang dimulai dari pengidentifikasian sejumlah Kontrol yang relevan untuk diterapkan dalam organisasi.

Sosialisasi keseluruhan piranti ke segenap lapisan manajemen dan karyawan organisasi untuk mendapatkan dukungan dan komitmen.

Para pihak berkepentingan lain yang berada di luar organisasi harus dilibatkan dalam proses sosialisasi karena mereka merupakan bagian yang tidak terpisahkan dari keamanan Informasi yang dibangun.

Keterlibatan para ahli dari luar organisasi untuk membantu organisasi menyusun kebutuhan dan mengidentifikasikan Kontrol yang dibutuhkan, sehingga keamanan Informasi yang dibangun dapat lebih efektif dan ekonomis.

\subsection{Keamanan Informasi}

Definisi Keamanan Informasi menurut (ISO 27001 dalam Sarno dan Iffano, 2009: 27) adalah penjagaan informasi dari seluruh ancaman yang mungkin terjadi dalam upaya untuk memastikan atau menjamin kelangsungan bisnis (business continuity), meminimasi risiko bisnis (reduce business risk) dan memaksimalkan atau mempercepat pengembalian investasi dan peluang bisnis
Definisi lain keamanan informasi menurut (SMKI dalam Sarno dan iffano, 2009:45) adalah suatu upaya untuk mengamankan aset informasi terhadap ancaman yang mungkin timbul. Maka keamanan informasi secara tidak langsung dapat menjamin kontinuitas bisnis, mengurangi risiko-risiko yang terjadi, mengoftimalkan pengembalian investasi (return on investment).

Bahwa ini berarti Kemanan informasi berkaitan upaya perlindungan atau mengamankan aset yang berharga terhadap kehilangan, pengungkapan penyalahgunaan, atau kerusakan yang mungkin terjadi upaya dalam menjamin kelangsungan bisnis (business continuity), meminimalkan risiko bisnis (reduce business risk) dan memaksimalkan pengembalian investasi dan peluang.

Keamanan bisa dicapai dengan beberapa cara atau strategi yang biasa dilakukan secara simultan atau dilakukan dalam kombinasi satu dengan lainnya. Strategi - strategi dari keamanan informasi masing - masing memiliki fokus dan dibangun dengan tujuan tertentu yang sesuai kebutuhan.

Keamanan informasi merupakan aspek penting dalam usaha melindungi aset informasi dari seoluruh ancaman yang mungkin terjadi dalam upaya untuk memastikan atau menjamin kelangsungan bisnis, meminimasi risiko bisnis dan memaksimalkan atau mempercepat pengembalian investasi dan peluang bisnis dalam sebuah organisasi. Jenis-jenis keamanan informasi dapat dibagi menjadi beberapa bagian sebagai berikut :

1. Keamanan Fisik (Physical Security)

Merupakan strategi untuk mengamankan individu atau anggota organisasi, aset fisik dan tempat kerja dari berbagai ancaman meliputi bahaya kebakaran, akses tanpa otorisasi dan bencana alam yang terjadi.

\section{Keamanan Pribadi (Personal Security)}

Merupakan bagian dari keamanan fisik yang berhubungana dengan melindungi personil/SDM pada organisasi yang memiliki akses terhadap informasi yang biasanya saling berhubungan dengan ruang linkup Phisical security.

\section{Keamanan Operasional (Operation Security)}

Keamanan Informasi Fokus yang membahas bagaimana strategi untuk mengamankan kemampuan organisasi untuk beroperasi tanpa ada gangguan.

\section{Keamanan Komunikasi (Communication Security)} Bertujuan mengamankan media komunikasi, teknologi komunikasi beserta isinya, serta kemampuan untuk memanfaatkan media dan teknologi komunikasi untuk mencapai tujuan organisasi.

\section{Keamanan Jaringan (Network Security)}

Fokus pada pengamatan peralatan jaringan data organisasi, jaringan beserta isinya, serta kemampuan untuk menggunakan jaringan dalam memenuhi fungsi komunikasi data organisasi.

Demikian Pentingnya sistem manajemen keamanan Informasi ini sehingga berbagai Regulasi telah dikeluarkan hal ini akan di bahas di sub Bab 2.6.8. 


\subsubsection{Karakteristik Keamanan Informasi}

Keamanan informasi juga memiliki 3 karakteristik penting yang disebut dengan singkatan CIA yaitu :

1. Confidentiality/ kerahasiaan: merupakan landasan utama dalam setiap kebijakan keamanan sistem informasi, yaitu seperangkat aturan yang diberikan, menentukan apakah suatu subjek tertentu dapat mendapatkan akses ke objek tertentu. memastikan bahwa informasi hanya dapat diakses oleh orang yang berwenang dan menjamin kerahasiaan data yang dikirim, diterima, dan disimpan.

2. Integrity/ kepercayaan: merupakan kepercayaan terhadap sebuah informasi yang ada. Keaslian informasi dapat terwujud jika informasi belum dirubah perubahan perubahan terjadi karena kesalahan secara sengaja maupun tidak.

3. Availability/ ketersediaan: merupakan ketersediaan sumber informasi ketika dibutuhkan. Ketersediaan ini dapat terpengaruh oleh faktor teknis, faktor alam, dan faktor manusia.

Ketiga karakteristik diatas saling berkaitan dan harus dipenuhi untuk menjaga keamanan informasi. Salah satu dukungan keamanan informasi adalah dengan adanya tata kelola keamanan informasi agar risiko keamanan informasi dapat dikurangi atau dihindari.

\subsubsection{Aspek Keamanan Informasi}

Perlindungan Informasi harus memenuhi aspek keamanan informasi, aspek ini harus diperhatikan, dikontrol, dipahami dan diterapkn dengan baik. Menurut Whitman dan Mattord (dalam Sarno dan Iffano, 2009: Hal 35) yaitu:

\section{a. Privacy}

Privacy menjamin keamanan data bagi pemilik. Informasi yang dikumpulkan, digunakan, dan disimpan oleh organisasi adalah dipergunakan hanya untuk tujuan tertentu, khusus bagi pemilik data saat informasi ini dikumpulkan.

b. Identification

Identifikasi adalah langkah pertama dalam memperoleh hak akses ke informasi yang diamankan, dimana Sistem informasi memiliki karakteristik identifikasi sistem bisa mengenali penggunaannya. Identifikasi umumnya dilakukan dengan penggunaan user name dan user ID.

c. Authentication

Autentikasi terjadi pada saat sistem dapat membuktikan bahwa pengguna memang benar-benar orang yang memiliki identitas yang di klaim.

d. Authorization

Setelah identitas pengguna diautentikasi, sebuah proses yang disebut autorisasi memberikan jaminan bahwa pengguna (manusia dan komputer) telah mendapatkan autorisasi secara spesifik dan jelas untuk mengakses, mengubah, atau menghapus isi dari informasi.

e. Accountability

Informasi hanya dapat diakses oleh orang yang berwenang dan menjamin kerahasiaan data yang dikirim, diterima dan disimpan.

\subsection{Sistem Manajemen Keamanan Informasi (SMKI)}

Pengertian Sistem manajemen keamanan informasi (SMKI) atau information security management system (ISMS). (SMKI dalam sarno dan iffano, 2009:46) merupakan suatu proses yang disusun berdasarkan pendekatan risiko bisnis untuk merencanakan (plan), mengimplementasikan dan mengoperasikan (Do), memonitor dan meninjau ulang (Check) serta memelihara dan meningkatkan atau mengembangkan (Act) terhadap keamnan informasi perusahaan. Keamanan Informasi ditujukan untuk menjaga aspek kerahasiaan, keutuhan, dan ketersediaan dari informasi

Sistem manajemen keamanan informasi yang diterapkan perusahaan atau instansi adalah dalam upaya mengamankan aset informasi terhadap ancaman yang mungkin terjadi. Oleh sebab itu, kemanan informasi secara tidak langsung menjamin kelangsungan bisnis perusahaan.

Sistem manajemen keamanan informasi menjadi penting diterapkan agar informasi yang beredar di perusahaan dapat dikelola dengan benar sehingga perusahaan dapat mengambil keputusan berdasarkan informasi yang ada dengan benar pula dalam rangka memberikan layanan yang terbaik kepada pelanggan. Tujuan dari SMKI sendiri adalah untuk meminimalisir risiko dan menjamin kelangsungan bisnis secara proaktif untuk membatasi dampak dari pelanggaran keamanan, dan keamanan informasi ditujukan yaitu untuk menjaga aspek Kerahasiaan (confidentiality), keutuhan (Integrity), dan ketersediaan (availability) dari informasi.

Sistem Manajemen Keamanan Informasi juga harus mengacu pada standar nasional atau internasional yang ada agar kualitas pengamanan yang diberikan tinggi dan mampu menanggulangi adanya masalah. Standar internasional yang telah direkomendasikan untuk penerapan SMKI adalah SNI ISO/IEC 27001:2013. Standar berjalan berbasis risiko sehingga mampu mengurangi ancaman dan menanggulangi masalah dengan cepat dan tepat. Dimana Implementasi dari SMKI ini meliputi kebijakan, proses, prosedur, struktur organisasi, serta fungsi dari software dan hardware.

Indonesia sendiri melalui BSN (Badan Standar Nasioanal ) kenapa mengadopsi pada standar ISO karena indonesia merupakan satu anggota bahkan menjadi anggota Dewan sehingga memiliki peran aktif dan penting dalam organisasi internasional tersebut, sehingga dengan demikian indonesia harus menjalankan kebijakan dan standar yang diterbitkan oleh ISO.

\subsubsection{Implementasi SMKI}

Bahwa SMKI adalah suatu pendekatan proses maka dalam mengimplementasikannya perlu dukungan mangemen yaitu :

1. Perencanaan (Planing) : yaitu melakukan kegiatan meliputi proses pernacangan, pembuatan dan implementasi untuk mencapai tujuan SMKI, tipe perancangan dalam SMKI antara lain:

a. Strategic planning (berhubungan dengan rencana jangka panjang): yang dilakukan oleh 
tingkstsn tertinggi dalam organisasi untuk periode yang lama, biasanya lima tahunan atau lebih

b. Tactical palnning (berhubungan dengan rencana jangka pendek) : memfokuskan diri pada pembuatan perencanaan dan mengintegrasi sumber daya organisasi pada tingkat yang lebih rendah dlam periode yang lebih singkat

c. Operational planning (berhubungan dengan rencana apa yang dilakukan dari hari ke hari): memfokuskan diri pada kinerja harian organisasi.

2. Kebijakan yaitu : peran dukungan kebijakan dari manajemen akan memberikan arahan dan dukungan sumber daya untuk mencapai tujuan SMKI, tanpa ada dukungan kebijakan dari pihak managemen organisasi SMKI tidak dapat dilakukan.

3. Program, dalam penyusunan SMKI didukung dengan pembangunan suatu prosedur dan proses secara detail tentang operasi-operasi dalam SMKI salah satunya adalah program pelatihan Keamanan Informasi

4. Penilaian Risiko yaitu : organisasi harus memahami seberapa besar dampak yang akan diterima oleh organisasi jika terjadi insiden keamanan Informasi. Penilaian risiko dilaksanakan berdasarkan serangkaian manajemen risiko meliputi Penilaian risiko (risk asessment).

5. Sumber Daya Manusia yaitu keamanan personil secara individu pada saat bekerjadan keamanan personil dalam organisasi

6. Tanggung Jawab yaitu tanggung jawab manajemen dalam penerapan SMKI, baik individu maupun tanggung jawab seluruh sumber daya organisasi untuk menjalankan dan memelihara SMKI.

\subsubsection{Perlunya SMKI}

Secara praktis memang tidak ada ketentuan bahwa menerapan terhimpuan teknik keamanan saja menjamin $100 \%$ aman. Meskipun teknik-teknik keamanan secara menyeluruh, belum cukup untuk memberikan jaminan keamanan.

Penerapan SMKI tidak bisa dilakukan secara terpisah yang berarti Keamanan Informasi adalah penerapan secara menyeluruh baik teknik keamanan yang terhimpun Teknologi Keamanan Informasi serta penjagaan aspek keamanan Informasi melalui prosesproses yang terhimpun dalam SMKI. Dengan demikian bahwa penerapan SMKI sangatlah penting karena ancaman terhadap aspek Keamanan Informasi semakin meningkat. Organisasi menghadapi ancaman terhadap informasi yang dimilikinya sehingga diperlukan langkahlangkah yang tepat untuk mengamankan dalam SMKI.

\subsection{ISO/IEC 27001}

ISO (International Organization for Standardization) adalah pengembang terbesar di dunia standar international secara sukarela. Standar international memberikan keamanan yang lebih spesifik, layanan yang baik, membantu industri lebih efisien dan efektif.

ISO/IEC 27001 merupakan standar keamanan informasi yang diterbitkan pada bulan Oktober 2005 oleh ISO dan IEC ( The International Electrotechnical Commission ). implementasi ISO/IEC 27001 mencakup pada semua organisasi seperti perusahaan swasta, lembaga, pemerintahan dan lembaga nirlaba. ISO/IEC 27001 adalah sebuah metode khusus yang terstruktur tentang pengamanan informasi yang diakui secara internasional. ISO/IEC 27001 merupakan dokumen standar sistem manajemen keamanan informasi atau Information Security Management Syestem, biasa disebut ISMS, yang memberikan gambaran secara umum mengenai apa saja yang harus dilakukan oleh sebuah perusahan dalam usaha mereka untuk mengevaluasi, mengimplementasikan dan memelihara keamanan informasi diperusahan berdasarkan "best practise" dalam pengamanan informasi. Standar ini menjelaskan syarat untuk membuat, menerapkan, memonitor, menganalisa dan memelihara serta mendokumentasikan SMKI dalam kontek risiko keamanan informasi organisasi keseluruhan. Standar ini menjelaskan pula bagaimana mendidkripsikan menetapkan, mengimplementasikan, mengoprasikan, mengamati, meninjau memelihara dan mengembangkan sistem.

ISO/IEC 27001 mendefinisikan pula keperluankeperluan untuk SMKI, sehingga SMKI yang baik akan membantu memberikan perlindungan terhadap gangguan pada aktivitas-aktivitas bisnis dan melindungi proses bisnis yang penting agar terhindar dari risiko dan kegagalan pengamanan sistem informasi, serta memberikan jaminan pemulihan operasi bisnis akibat kerugian yang timbulkan.

ISO/IEC 27001 diterapkan tidak selalu harus digunakan dari keseluruhan kontrol melainkan disesuaikan dengan kebutuhan kontrol dari organisasi masing-masing.

\subsubsection{Pemilihan SNI ISO/IEC 27001:2013}

Beberapa alasan yang patut dijadikan pertimbangan kenapa dipilih standar SNI ISO/IEC 27001:2013 diantaranya:

1. Sudah diadopsi oleh Indonesia melalui BSN (Badan Standardisasi Nasional).

2. Sudah ditetapkan oleh Kementrian Komunikasi dan Informatika mengenai standar dengan diterbitkan Permen (Peraturan Kementrian).

3. Menyediakan model lengkap terkait bagaimana melakukan : membangun,

implementasi, operasional, memonitor, mengkaji ulang, memelihara dan mengembangkan SMKI.

4. SNI ISO/IEC 27001:2013 Implementasi SMKI didesain menjadi fleksibel karena tergantung dari : kebutuhan organisasi, tujuan organisasi yang dicapai, persyaratan keamanan yang diperlukan, proses bisnis yang ada, jumlah pegawai dan ukuran struktur organisasi. Dengan kata lain bahwa menggunakan SNI ISO/IEC 27001:2013 dalam implementasinya bisa sangat tergantung kebutuhan organisasi.

5. SNI ISO/IEC 27001:2013 menyedikan sertifikat implementasi SMKI yang diakui secara internasional yang disebut ISMS Sertification.

\subsubsection{Struktur SNI ISO/IEC 27001:2013}

Dalam membangun SMKI menggunakan standar SNI ISO/IEC 27001:2013 perlu diperhatikan dan dipahami bahwa struktur organisasi SNI ISO/IEC 27001:2013 memiliki dua bagian yaitu; 
1. Kalusul : Mandatori Proses, kalusul (pasal) adalah persaratan yang harus dipenuhi oleh organisasi

2. Annex A: Sequrity Control, yaitu dokumen referensi yang disediakan dan dapat dijadikan rujukan untuk menentukan kontrol keamanan yang perlu diimplementasikan didalam SMKI yang terdiri dari 14 Kalusul kontrol Keamanan, 13 objektif Kontrol dan 114 Kontrol.

Selain itu yang perlu diperhatikan dan dipahami yaitu struktur isi dokumen sebagai rujukan persyaratan apa yang harus dipenuhi saat membangun SMKI adapun kaitan dengan SMKI maka ISO/IEC 27001 terdapat di Klausul 4.

\subsection{SNI ISO/IEC 27005:2013}

Standar ini memberikan pedoman untuk Manajemen Risiko Keamanan Informasi dalam suatu organisasi, mendukung khususnya persyaratan Sistem Manajemen Keamanan Informasi (SMKI) sesuai dengan ISO/1EC 27001. untuk membantu pelaksanaan yang memuaskan dari keamanan informasi berdasarkan pendekatan manajemen risiko.

Standar ini berlaku pada semua jenis organisasi (misalnya perusahaan komersial, instansi pemerintah, organisasi non-profit) yang berniat untuk mengelola risiko yang dapat membahayakan keamanan informasi organisasi.

\subsection{Manajemen Risiko}

\subsubsection{Pengertian Risiko}

Adalah peluang terjadinya sesuatu yang memberikan dampak atau mengakibatkan terganggunya proses bisnis organisasi sampai menyebabkan gagalnya tujuan bisnis organisasi. Risiko ini diukur berdasarkan dampak yang ditimbulkan terhadap kemungkinan terjadinya risiko.

\subsubsection{Pengertian Manajemen Risiko}

Adalah proses untuk mengidentifikasi risiko, menganalisa risiko, dan melakukan penanganan untuk mengurangi risiko sampai dampaknya terhadap proses bisnis di organisasi pada level yang diterima atau diperbolehkan.

Pengelolaan risiko adalah suatu aktivitas organisasi yang terkoordinasi yang mengarahkan dan mengontrol organisasi untuk menghadapi suatu risiko yang berhubungan dengan proses bisnisnya. Secara garis besarnya organisasi harus memahami : risiko apa yang dihadapi yang hubunganya dengan keamanan informasi, kelemahan dan ancaman terhadap informasi, cara terbaik untuk menghadapi risiko, dan menentukan kontrolkontrol keamanan yeng berhubungan dengan risiko yang timbul.

Hubungan dengan membangun SMKI adalah pelaksanaan manajemen risiko meliputi langkah-langkah

\footnotetext{
- Melakukan inventarisasi aset

- Melakukan penilain risiko

- Cara penanganan risiko
}

\subsubsection{Penilaian Risiko}

Penilaian risiko mengukur atau menggambarkan secara kualitatif suatu

risiko dan memungkinkan manajer untuk memprioritaskan risiko sesuai dengan keseriusan yang mereka rasakan atau kriteria lain yang telah ditetapkan. Penilaian risiko memuat kegiatan-kegiatan berikut:

1. Analisis risiko yang terdiri dari:

- Identifikasi risiko

- Estimasi risiko

2. Evaluasi risiko

Penilaian risiko menentukan nilai aset informasi, mengidentifikasi ancaman- ancaman yang berlaku dan kerentanan yang ada (atau bisa ada), mengidentifikasi kontrol yang ada dan efeknya pada risiko yang teridentifikasi, menentukan konsekuensi potensial dan akhirnya memprioritaskan risiko yang diperoleh dan menggolongkan terhadap kriteria evaluasi risiko yang diatur dalam penetapan konteks.

\subsubsection{Menentukan Nilai Risiko}

Adalah gambaran dari seberapa besar akibat yang akan diterima organisasi jika ancaman yang menyebabkan kegagalan keamanan Informasi terjadi. Adapun niilai risiko ditentukan oleh metode :

\section{Metode Kualitatif}

Membuat perkiraan terhadap biaya yang ditanggung oleh organisasi akibat dari risiko yang diterima. Nilai risiko ditentukan dengan range :

$$
\begin{array}{ll}
\text { - } & \text { Low Risk (risiko Kecil = 0-2) } \\
\text { - } & \text { Medium Risk (risiko sedang =3-5) } \\
\text { - } & \text { High Risk ( risiko Tinggi=6-8) }
\end{array}
$$

Banyak cara untuk menghubungkan faktor-faktor tersebut, seperti contoh, nilai diberikan kepada aset, kerentanan, dan ancaman digabungkan untuk mendapatkan nilai risiko yang diukur, seperti metode yang menggunakan tabel seperti tabel dibawah ini.

\begin{tabular}{|c|c|c|c|c|c|c|c|c|c|c|}
\hline & $\begin{array}{l}\text { Kemungkinan } \\
\text { terjadi }\end{array}$ & \multicolumn{3}{|c|}{$\begin{array}{l}\text { Rendah } \\
\text { (R) }\end{array}$} & \multicolumn{3}{|c|}{$\begin{array}{l}\text { Sedang } \\
\text { (S) }\end{array}$} & \multicolumn{3}{|c|}{$\begin{array}{l}\text { Tinggi } \\
\text { (T) }\end{array}$} \\
\hline & Kemudah & $\mathrm{R}$ & $\mathrm{S}$ & $\mathrm{T}$ & $\mathrm{R}$ & $\mathrm{S}$ & $\mathrm{T}$ & $\mathrm{R}$ & $\mathrm{S}$ & $\mathrm{T}$ \\
\hline \multirow{5}{*}{ 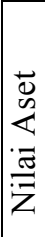 } & 0 & 0 & 1 & 2 & 1 & 2 & 3 & 2 & 3 & 4 \\
\hline & 1 & 1 & 2 & 3 & 2 & 3 & 4 & 3 & 4 & 5 \\
\hline & 2 & 2 & 3 & 4 & 3 & 4 & 5 & 4 & 5 & 6 \\
\hline & 3 & 3 & 4 & 5 & 4 & 5 & 6 & 5 & 6 & 7 \\
\hline & 4 & 4 & 5 & 6 & 5 & 6 & 7 & 6 & 7 & 8 \\
\hline
\end{tabular}

Tabel 2.1 Matriks nilai aset, kemungkinan terjadi, dan kemudahan eksploitasi

Sumber BSN SNI ISO 27005:2013

Sebagai contoh untuk menentukan peringkat nilai risiko yang ditangani, jika sebuah aset mempunyai nilai 3, ancamannya "high" dan kerentanannya "low", maka nilai dari risikonya adalah 5. Ukuran matriks, dalam hal jumlah kategori keparahan ancaman, kategori keparahan kerentanan, dan jumlah kategori penilaian aset, dapat disesuaikan dengan kebutuhan organisasi.

Tabel dibawah memetakan kemungkinan ini terhadap dampak bisnis yang terkait dengan skenario insiden. 
Risiko yang timbul diukur pada skala 0 sampai 8 yang dapat dievaluasi terhadap kriteria penerimaan risiko. Skala risiko ini juga bisa dipetakan ke peringkat risiko keseluruhan yang sederhana,

Tabel 2.2 Matriks kemungkinan skenario insiden dan dampak bisnis

\begin{tabular}{|c|c|c|c|c|c|c|}
\hline \\
\hline & $\begin{array}{c}\text { Kemungkina } \\
\mathrm{n}\end{array}$ & 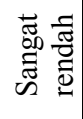 & 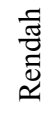 & $\begin{array}{l}0 \\
\text { 胥 } \\
\tilde{D}\end{array}$ & $\begin{array}{l}\sqrt{50} \\
00 \\
.\end{array}$ & 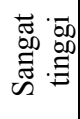 \\
\hline \multirow{5}{*}{ 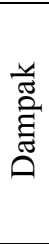 } & $\begin{array}{l}\text { Sangat } \\
\text { rendah }\end{array}$ & 0 & 1 & 2 & 3 & 4 \\
\hline & Rendah & 1 & 2 & 3 & 4 & 5 \\
\hline & Sedang & 2 & 3 & 4 & 5 & 6 \\
\hline & Tinggi & 3 & 4 & 5 & 6 & 7 \\
\hline & Sangat tinggi & 4 & 5 & 6 & 7 & 8 \\
\hline
\end{tabular}

(sumber BSN SNI ISO/IEC 27005:2013)

\subsubsection{Identifikasi Ancaman}

Ancaman memiliki potensi untuk membahayakan aset seperti informasi, proses dan sistem dan oleh karena itu organisasi. Ancaman mungkin berasal dari alam atau manusia, dan bisa tidak disengaja atau disengaja. Sumber ancaman baik tidak disengaja dan disengaja harus diidentifikasi. Ancaman mungkin timbul dari dalam atau dari luar organisasi. Ancaman harus diidentifikasi secara umum dan menurut jenis (misalnya tindakan yang tidak sah, kerusakan fisik, kegagalan). Hasilnya Sebuah daftar ancaman dengan identifikasi jenis ancaman dan sumbernya.

\subsubsection{Identifikasi Kerentanan}

Sebuah daftar ancaman yang diketahui, daftar aset dan kontrol yang ada. Kerentanan yang dapat dieksploitasi oleh ancaman untuk membahayakan aset atau organisasi harus diidentifikasi. Kerentanan dapat diidentifikasi dalam bidang-bidang berikut: Organisasi, Proses dan prosedur, Rutinitas manajemen, Personel, Lingkungan, fisik, Konfigurasi sistem Informasi, Perangkat keras, perangkat lunak atau peralatan komunikasi, Ketergantungan pada pihak luar

Kemudian hasilnya adalah daftar kerentanan dalam kaitannya dengan aset, ancaman dan kontrol; daftar kerentanan yang tidak berhubungan dengan ancaman diidentifikasi untuk ulasan.

\subsubsection{Evaluasi Risiko}

Sebuah daftar risiko dengan tingkat nilai yang diberikan dan kriteria evaluasi risiko sifat dari keputusan yang berkaitan dengan evaluasi risiko dan kriteria evaluasi risiko yang akan digunakan untuk membuat keputusan telah diputuskan ketika menentukan konteks. Keputusan dan konteks ini harus ditinjau kembali secara lebih rinci pada tahap ini ketika telah mengetahui lebih dalam tentang risiko tertentu yang teridentifikasi. Hasilnya adalah Sebuah daftar risiko yang diprioritaskan menurut kriteria evaluasi risiko dalam kaitannya dengan skenario insiden yang mengarah ke risiko tersebut.

Sebuah daftar risiko yang diprioritaskan menurut risiko kriteria evaluasi dalam kaitannya dengan skenario insiden yang mengarah ke risiko tersebut. Adapun
Tindakan yang dilakukan adalah Kontrol untuk mengurangi, mempertahankan, menghindari, atau mentransfer risiko harus dipilih dan rencana penanganan ditetapkan dan langkah-langkah pelaksanaan yaitu Ada empat pilihan yang tersedia untuk penanganan risiko yaitu mengurangi risiko mempertahankan risiko, menghindari risiko dan mentransfer risiko.

\section{Metode Penelitian}

Metode penelitian yang digunakan dalam penelitian ini merupakan metodologi kualitatif dengan mendeskripsikan bagaimana Perancangan Mnajemen keamanan informasi berdasarkan manajemen resiko yang terjadi di LPSE Kabupaten Cianjur.

\subsection{Kerangka Penelitian}

Kerangka penelitian merupakan alur yang dibangun secara terstruktur dan sistematis sebagai suatu acuan tahapan dalam menyelesaikan masalah penelitian. Tahapan pada kerangka penelitian ini akan saling berkaitan antara satu proses dengan proses yang lainnya. Hasil dari suatu tahapan akan digunakan sebagai masukkan untuk tahapan selanjutnya.

Langkah Kerangka pada penelitian ini sebagai berikut:

\begin{tabular}{|c|c|c|}
\hline \multicolumn{3}{|c|}{ 1. Dukungan Manajemen } \\
\hline \multicolumn{3}{|c|}{ 2. Pengumpulan data } \\
\hline $\begin{array}{l}\text { Daftar } \\
\text { Pustaka }\end{array}$ & Wawancara/Kuesioner & Observasi \\
\hline \multicolumn{3}{|c|}{ 3. Ruang lingkup } \\
\hline \multicolumn{3}{|c|}{ 4. Identifikasi Aset } \\
\hline \multicolumn{3}{|c|}{ 5. Inventarisasi informasi } \\
\hline \multicolumn{3}{|c|}{ 6. Pengelolaan Risiko } \\
\hline \multicolumn{3}{|c|}{ - $\quad$ Identifikasi Risiko } \\
\hline Ancaman & Kelemahan & \\
\hline \multicolumn{3}{|c|}{ - $\quad$ Analisis Risiko } \\
\hline \multicolumn{3}{|c|}{ - $\quad$ Mengukur Risiko } \\
\hline \multicolumn{3}{|c|}{ 7. Risk treatment } \\
\hline \multicolumn{3}{|c|}{ 8. Membuat rencana implementasi SMKI } \\
\hline \multicolumn{3}{|c|}{ 9. Kesimpulan dan saran } \\
\hline
\end{tabular}

\subsection{Dukungan Manajemen}

Dalam membangun SMKI Dukungan manajemen adalah persyaratan ISO/IEC 27001 jadi Sebelum SMKI dibangun pihak manajemen harus memberikan dukungan kepada organisasi dalam melaksanakan SMKI yaitu :

1. Persyaratan komitmen

2. Membuat dan menentukan kebijakan SMKI

3. Bertanggungjawab dan memonitor pelaksanaan SMKI

4. Menyediakan atau memberikan pasilitas yang diperlukan dalam melaksanakan SMKI

Bentuk dari Dukungan manajemen berupa pernyataan dokumen komitmen yang telah disetujui dari pihak manajemen.

Pada tahap ini peneliti melakukan permohonan ijin penelitian melalui surat perihal ijin permohonan dengan diterbitkan surat No 379/UNLA/PPs/VIII/2017 yang ditujukan kepada Kepala Dinas Komunikasi dan Informatika Kabupaten Cianjur. Seterusnya dari pihak 
Dinas Komunikasi dan Informatika atau dari Kepala Dinas melalui surat balasan menyatakan mendukung untuk melakukan penelitian sesuai dengan judul Tesis Peneliti, dan diterbitkan surat no 070/519/Diskominfo/X/2017.

\subsection{Pengumpulan Data}

Pada tahap ini akan dilakukan pengumpulan data-data terkait Tesis yang akan dikerjakan. Dimana Data yang diperoleh dari Dinas Komunikasi dan Informatika Kabupaten Cianjur di bagian LPSE. Data diperoleh selama melakukan wawancara dan observasi secara langsung oleh peneliti. Data ini adalah sebagi bukti pendukung berupa dokumen-dokumen yang dapat memperkuat pernyataan dari pihak yang diwawancara. Peneliti melakukan wawancara dengan Kepala Unit LPSE, Kabid-Kabid Administrasi, Registrasi dan Verifikasi, Layanan Pengguna dan Pelatihan.

Dokumen-dokumen/informasi yang didapat dari narasumber tidak lepas dari area ISO/IEC 27001 SNI 2013 sesuai dengan klausul yang direncanakan yaitu: Area : Kalusul A 7 Sumber Daya manusia, Klausul A8 Manajemen Aset, Klausul A9 Kontrol Akses, Klausul A 11 Keamanan Fisik dan lingkungan dan Klausul A13 Keamanan Komunikasi

\subsubsection{Instrumen Wawancara}

Wawancara menurut Creswell (2012) merekam jawaban atas pertanyaan yang diberikan kepada responden, dimana peniliti mengajukan pertanyaan kepada responden dengan pedoman wawancara, mendengarkan atas jawaban, mengamati prilaku dan merekam semua respon dari yang disurvei. Selanjutnya menurut larry Cristensen (2004) mengatakan wawancara merupakan teknik pengumpulan data dimana pewancara dalam mengumpulkan data mengajukan suatu pertanyaan kepada yang diwawancarai. (sugiono, 2013:188)

Dari kedua pernyataan di atas maka dapat disimpulkan bahwa wawancara merupakan suatu teknik pengumpulan data dimana peniliti harus menyiapkan Instrumen wawancara berupa daftar pertanyaan yang akan diajukan pada saat wawancara dengan narasumber. instrumen wawancara yang digunakan ada dua kategori yaitu dalam bentuk pertanyaan dan kuesioner

Wawancara akan dilakukan kepada narasumber berdasarkan kapasitas serta kewenangannya untuk memberikan informasi yang benar-benar sesuai dengan pertanyaan yang diajukan supaya untuk menghindari terjadinya kesalahan informasi. Instrumen wawancara yang akan digunakan untuk pengumpulan data.

Tahap pertama yaitu melakukan wawancara dengan narasumber sekretaris kepala Unit LPSE dengan pertanyaan sebgai berikut

1. Apakah di instansi anda sudah memiliki standar kebijakan dan standar operasi prosedur dalam pengamanan informasi terkait dengan sumber daya manusia?

Pada saat ini belum memiliki secara terdokumentasi, tetapi dari sisi teknis pelaksanaan, aturan-aturan sudah diterapkan seperti : a. Seleksi Calon Pegawai, penyeleksian kualifikasi calon karyawan dari mulai syarat pendaftaran, jenjang akademik, tes tulis tentang kompetensi keahlian sampai pada tes akhir (wawancara) sudah diselenggarakan

b. Tanggung jawab karyawan (job description) secara umum terhadap keamanan informasi sudah direalisasikaan seperti ada statment dilarang masuk tanpa ada ijin petugas, setiap karyawan ditempatkan pada posisi ruang masing-masing sudah ditentukan dengan pemberian label informasi.

2. Apakah di instansi anda sudah memiliki dokumen kebijakan tentang prosedur keamanan informasi terhadap aset yang dimiliki ?

Belum memiliki, baru tahap menginventalisir aset yang ada berupa tabel aset dalam dokumen excel yang disebut kartu inventarisasi barang, pelabelan hanya untuk mengidentifikasi aset yang dimiliki belum di buat skema klasifikasi informasi dan penanganan informasi, serta belum menspesifikasikan tingkat risiko dari setiap aset jika terjadi insiden.

3. Apakah pada instansi anda sudah memiliki dokumen kebijakan terkait keamanan informasi terhadap pengendalian akses kontrol?

a. Secara keseluruhan belum memiliki ada beberapa bagian tertentu aturan sudah tertulis seperti aturan pembuatan User ID dan password, registari dan verifikasi pendaftaran pengguna. Sehingga dengan keterbatasan ini sering muncul penggunaan akses disalahgunakan yaitu pengguna memanfaatkan akses untuk main game secara on-line, membuka jejaring sosial (Facebook, Chatting, on-line shop, you tube).

b. Selain itu kekurangan dari pelaksanaan pengelolaan aset informasi yaitu belum adanya undangundang yang digunakan untuk klasifikasi aset, tanggung jawab per individu belum dijabarkan secara keseluruhan.

c. Tidak ada tata tertib terkait penggunaan e-mail dan komputer

d. Tidak ada kebijakan tertulis untuk pengelolaan password dan username

e. Prosedur untuk mutasi user masih dalam perencanaan.

f. Belum adanya mekanisme pengamanan fisik dalam pengiriman aset

4. Apakah pada instansi anda sudah memiliki aturan terdokumentasi untuk keamanan fisik dan lingkungan ( lokasi kerja, kantor: ruang server, ruang arsip, instalasi pengkabelan, sumber daya, dan infrastruktur komputasi)?

Belum ada dokumen resmi tapi sudah ada beberapa bagian secara implementasi sudah dilakukan dalam hal pengamanan, diantaranya :

a. Lokasi kerja letaknya strategis ada di pusat kota, relatif jauh dari lingkungan rumah penduduk, sehingga kemungkinan terjadinya pencurian aset bisa diminimalisir.

b. Ruang kerja sudah dibuatkan partisi/pembagian ruang dan diberikan label untuk pengguna yang sudah ditunjuk, sehingga kemungkinan tidak akan terjadi insiden.

c. Komputer desktop diletakkan pada meja sudah ada pengamanan dari pencurian, misalkan casing CPU disimpan bersatu dengan meja kerja dan bila sudah tidak 
digunakan langsung dikunci. Layar monitor sudah dipasang penguat yang di tempelkan dengan meja kerja.

d. Bila terjadi kegagalan sumber daya (gangguan Listrik, petir) sudah disiapkan ATS Otomatis atau jenset sudah disiapkan.

e. Server 24 jam on-line yang diletakkan pada ruang khusus dengan jalur satu pintu, dan tertera larangan masuk, kemudian setelah selesai jam kerja pintu ditutup dan dikunci. Untuk ke depan kontruksi ruang dalam hal peningkatan perlindungan fisik masih dalam tahap pengajuan.

f. Belum adanya bagian-bagian tertentu yang bertanggung jawab langsung dalam mengelola risiko keamanan informasi, belum adanya kerangka kerja risiko yang digunakan, tidak ada pencatatan terkait penyelesaian risiko, dan tidak ada dokumen yang mendaftar semua ancaman terkait aset informasi

5. Apakah di instansi anda sudah memiliki standar konfigurasi instalasi jaringan komputer dalam hal keamanan komunikasi dan apakah sudah terjadi insiden terhadap aplikasi LPSE serta adakah tindakan terhadap kontrol keamanan yang diterapkan?

a. Jaringan komputer sudah terpasang, tapi konfigurasi instalasi jaringan

komputer belum memiliki standar atau adopsi yang resmi, baru fasilitas lingkup syarat minimal terjadi komunikasi yaitu ada server, komputer, LAN, Internet, telepon dan Fax. Sudah ada tahap persiapan yang dilakukan yaitu mengirimkan staf untuk mengikuti pelatihan instalasi Server LPSE, Instalasi komputer dan instalasi jaringan LAN dan Internet.

b. Sampai saat ini sudah terjadi insiden namun tidak secara signifikan, seperti ditemukan virus yang terjadi ketika ada pemback up data atau pengiriman data melalui flash disk atau CD. Selain itu ada e-mail SPAM.

c. Untuk tindakan kontrol keamanan dalam aplikasi dipasang firewall, antivirus, layanan bidding room, training room, dan helpdesk .

\subsubsection{Kuesioner}

Tahap kedua ini peniliti memberiikan instrumen pertanyaan kepada responden untuk melakukan pengisian kuesioner tujuannya adalah untuk mengevaluasi tingkat ketersediaan dokumen terkait dengan klausul dan kontrol-kontrol keamanan yang ada di ISO/IEC 27001 SNI 2013. Adapun narasumber yang mengisi kuesioner adalah sekretaris Kepala Unit LPSE, Bidang Administrasi sistem informasi, Bidang registrasi dan Verifikasi. Berikut contoh hasil kuesioner pada Tabel 3.2.
Tabel 3.2. Tabel Kuesioner

\begin{tabular}{|c|c|c|c|}
\hline \multicolumn{2}{|r|}{ Klausul A.8 Manajemen Aset } & $\begin{array}{c}\text { SNI } \\
\text { ISO/IEC } \\
27001: 2 \\
013\end{array}$ & Skor \\
\hline \multicolumn{2}{|c|}{$\begin{array}{l}\text { Tanggung Jawab terhadap aset } \\
\text { Untuk memenuhi perlindungan dan } \\
\text { pemeliharaan terhadap aset organisasi }\end{array}$} & A.8.1 & \\
\hline 1. & Inventarisasi terhadap Aset & A.8.1.1 & 3 \\
\hline 2. & Kepemilikan aset & A.8.1.2 & 3 \\
\hline 3. & Aturan penggunaan Aset & A.8.1.3 & 2 \\
\hline 4. & Pengembalian aset & A.8.1.4 & 2 \\
\hline 5. & Aturan klasifikasi & A.8.2.1 & 2 \\
\hline 6. & pelabelan informasi & A.8.2.2 & 2 \\
\hline 7. & Penanganan aset & A.8.2.3 & 2 \\
\hline 8. & Pengelolaan data yang dihapus & A 8.3 .1 & 1 \\
\hline 9. & Penghancuran media & A.8.3.2 & 1 \\
\hline 10. & Transfer media Fisik & A.8.3.3 & 1 \\
\hline \multicolumn{2}{|c|}{ Nilai Rata-rata } & & 1.9 \\
\hline \multicolumn{4}{|c|}{ Dan seterusnya } \\
\hline
\end{tabular}

\subsubsection{Observasi}

Selain melakukan kegiatan wawancara juga melakukan observasi yaitu teknik pengumpulan data secara spesifik dengan melakukan kunjungan langsung ke lokasi penelelitian untuk mengamati dan ingatan yang sebenarnya keadaan LPSE Kabupaten Cianjur mulai dari prilaku SDM, proses kerja dan penomena yang diinginkan sebagai alasan untuk mendukung dan memperkuat dari hasil wawancara.

\subsubsection{Menentukan Ruang Lingkup SMKI}

Adalah menentukan ruang lingkup implementasi SMKI, artinya SMKI diterapkan dalam organisasi hanya bagian yang penting. Organisasi berkomitmen melindungi informasi. Penentuan ini berdasarkan : Kebutuhan organisasi, Karakteristik bisnis organisasi, Lokasi dari organisasi, Aset yang dimiliki oleh organisasi dan Teknologi Informasi yang telah digunakan

Adapun SMKI organisasi diimplementasikan untuk ruang lingkup bisnis organisasi yaitu pada bagian :

a. LPSE pada Dinas Komunikasi Informasi Dan informatika Kabupaten Cianjur

b. Aset informasi dan Infrastruktur LPSE yang digunakan untuk aktivitas bisnis

\subsubsection{Identifikasi Aset}

Proses identifikasi aset merupakan proses pengidentifikasian pada aset-aset yang dimiliki oleh unit LPSE Komunikasi dan Informatika Kabupaten Cianjur. melalui survei ke unit LPSE serta melakukan observasi dan wawancara kepada pihak terkait dari penelitian. Adapun hasil dari identifikasi kemudian diklasifikasikan berdasarkan kategori aset yang disesuaikan dengan dengan ruang lingkup SMKI, berikut contoh pada tabel 3.3 tentang aset berdasarkan kategori: 


Tabel 3.3 Tabel Aset
\begin{tabular}{|c|l|ll|}
\hline No. & \multicolumn{1}{|c|}{ Kategori Aset } & \multicolumn{2}{l|}{ Nama Aset } \\
\hline 1 & Informasi & $\bullet$ & Data pegawai \\
\hline 2 & Perangkat keras dan jaringa & $\bullet$ & Server SPSE \\
\hline 3 & Perangkat Lunak & $\bullet$ & Sistem \\
& & & Operasi \\
\hline 4 & Sumber Daya Manusia (SDM) & $\bullet$ & Pegawai \\
\hline 5 & Failitas pendukung & $\bullet$ & Genset \\
\hline 6 & Pasilitas & $\bullet$ & Lemari arsip \\
\hline
\end{tabular}

\subsubsection{Inventarisasi Informasi}

Melakukan pendataan informasi dengan maksud agar organisasi memahami informasi apa saja yang dimiliki oleh organisasi dan seberapa pentingnya setiap informasi yang dimiliki. Aset ini antara lain : informasi, pernagkat keras, jaringan, perangkat lunak, fisik, layanan, dan orang.

\subsubsection{Pengelolaan Risiko (Risk Management)}

Setelah dilakukannya tahapan pengambilan data berupa identifikasi aset, tahap selanjutnya adalah melakukan analisa risiko, dimana dalam analisa risiko terdapat beberapa poin yang harus dianalisa seperti identifikasi risiko berdasarkan confidentiality, integrity dan availabilty, selanjutnya melakukan analisa kecenderungan dan analisa dampak yang ada pada aset. Melakukan manjemen risiko dengan tepat terhadap informasi yang dimiliki dan yang telah didata oleh organisasi.

Hasil dari wawancara ini nantinya akan digunakan pada tahap penilaian atau dengan kata lain untuk memetakan posisi LPSE Kabupaten Cianjur dengan kriteria Pengelolaan Risiko Keamanan Informasi. Pengelolaan risiko keamanan informasi yaitu sudah ditentukan batas ambang risiko yang dapat diterima, ada pencatatan mengenai kepemilikan aset, dilakukan kajian risiko terkait dampak dan mitigasi risiko.

\subsubsection{Membuat Rencana Implementasi}

Tahap implementasi merupakan tahapan terakhir dari penelitian. Ada 2 langkah yang dilakukan dalam tahapan penerapan ini yaitu : Pemetaan Objective kontrol \& control serta pembuatan kebijakan dan standar operasional prosedur keamanan informasi. Dimana pembuatan kebijakan dan standar opersional prosedur ini merupakan tujuan utama dalam penelitian.

Rencana implementasi berisi :

- Mendapatkan persetujuan manajemen tentang rencana pelaksanaan SMKI, manajemen membuat suatu pernyataan tentang kebijakan SMKI.

- $\quad$ Menetapkan ruang lingkup

- Menetapkan metode pengolahan risiko

- Membuat dokumen rencana implementasi dengan istilah SOA (statement of applicability)

- $\quad$ langkah merencanakan implementasi

\section{Analisis dan Pembahasan}

\subsection{Hasil Analisis Identifikasi Aset}

\subsubsection{Penilaian Aset dan Dampak}

Langkah selanjutnya setelah identifikasi aset adalah untuk menyepakati skala yang akan digunakan dan kriteria untuk menetapkan lokasi tertentu pada skala untuk setiap aset, berdasarkan penilaian. Untuk penentuan skala penilaian berdasarakan ketergantungan pada proses bisnis. Dapat dilihat pada tabel 4.1

Tabel 4.1 Penilaian Aset dan dampak

\begin{tabular}{|c|c|c|c|c|}
\hline No. & $\begin{array}{l}\text { Kategor } \\
\text { i Aset }\end{array}$ & Nama Aset & 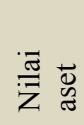 & $\begin{array}{l}\frac{y}{\tilde{J}} \\
\text { हैँ } \\
\text { ڤ్ }\end{array}$ \\
\hline 1 & $\begin{array}{l}\text { Informa } \\
\text { si }\end{array}$ & $\begin{array}{l}\text { - Data pegawai } \\
\text { - Data penyedia barang } \\
\text { dan jasa } \\
\text { - Data lelang } \\
\text { - Data Pengadaan } \\
\text { - Back up CD data } \\
\text { pengadaan }\end{array}$ & $\begin{array}{l}2 \\
2 \\
3 \\
3 \\
2\end{array}$ & $\begin{array}{l}2 \\
2 \\
3 \\
3 \\
3 \\
2\end{array}$ \\
\hline 2 & $\begin{array}{l}\text { Perangk } \\
\text { at keras } \\
\text { dan } \\
\text { jaringan }\end{array}$ & $\begin{array}{ll}\text { - } & \text { Platform hardware } \\
\text { - } & \text { Komputer server } \\
\text { - } & \text { Komputer desktop } \\
\text { - } & \text { Laptop } \\
\text { - } & \text { Printer } \\
\text { - } & \text { HUB } \\
\text { - } & \text { Switch } \\
\text { - } & \text { Router/Bridge } \\
\text { - } & \text { Jaringan LAN } \\
\text { - } & \text { Internet (Asti Net) } \\
\text { - } & \text { Server SPSE }\end{array}$ & $\begin{array}{l}3 \\
3 \\
3 \\
3 \\
3 \\
3 \\
3 \\
3 \\
3 \\
3 \\
3 \\
3 \\
3\end{array}$ & $\begin{array}{l}3 \\
3 \\
2 \\
3 \\
2 \\
2 \\
2 \\
3 \\
3 \\
3 \\
3 \\
3\end{array}$ \\
\hline & & $\begin{array}{ll}\text { - Jaringan Telephon } \\
\text { - Jaringan Fax } \\
\end{array}$ & $\begin{array}{l}2 \\
2 \\
\end{array}$ & $\begin{array}{l}2 \\
2 \\
\end{array}$ \\
\hline 3 & $\begin{array}{l}\text { Perangk } \\
\text { at Lunak }\end{array}$ & 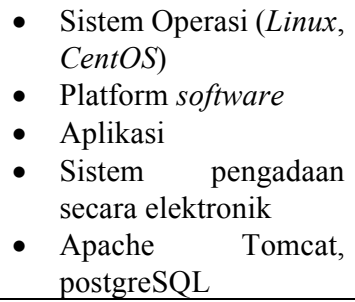 & $\begin{array}{l}3 \\
3 \\
3 \\
3 \\
3\end{array}$ & $\begin{array}{l}3 \\
2 \\
2 \\
3 \\
3 \\
3\end{array}$ \\
\hline 4 & $\begin{array}{l}\text { Sumber } \\
\text { Daya } \\
\text { Manusia } \\
\text { (SDM) }\end{array}$ & $\begin{array}{ll}\text { - } & \text { Kepala unit } \\
\text { - } & \text { Kepala Bidang } \\
\text { - } & \text { Pegawai Tetap } \\
\text { - } & \text { Pengawai kontrak }\end{array}$ & $\begin{array}{l}3 \\
3 \\
3 \\
2\end{array}$ & $\begin{array}{l}2 \\
2 \\
2 \\
1\end{array}$ \\
\hline 5 & $\begin{array}{l}\text { Pailitas } \\
\text { penduku } \\
\text { ng }\end{array}$ & $\begin{array}{l}\text { - Genset otomatis } \\
\text { - } \mathrm{AC}\end{array}$ & $\begin{array}{l}3 \\
3\end{array}$ & $\begin{array}{l}3 \\
2\end{array}$ \\
\hline 6 & Pasilitas & $\begin{array}{ll}\text { - } & \text { Ruang penyimpanan } \\
& \text { server } \\
\text { - } & \text { Lemari arsip } \\
\text { - } & \text { Rak server } \\
\text { - } & \text { Ruang pelatihan }\end{array}$ & $\begin{array}{l}3 \\
3 \\
2 \\
2\end{array}$ & $\begin{array}{l}2 \\
2 \\
2 \\
2\end{array}$ \\
\hline
\end{tabular}

Untuk menentukan rentang nilai angka kategori sistem elektronik diambil dari Peraturan Menteri Komunikasi Dan Informatika Republik Indonesia No 4 tahun 2016 Tentang Sistem Manajemen Keamanan Informasi dan Index KAMI tahun 2013.

\subsubsection{Identifikasi Ancaman}

Tahap selanjutnya adalah mengidentifikasi kemungkinan terjadinya ancaman-ancaman ini dapat digunakan selama proses penilaian ancaman. Ancaman mungkin disengaja, tidak disengaja atau lingkungan (alam) dan dapat mengakibatkan, sebagai contoh, pada kerusakan atau kehilangan layanan penting. Daftar berikut menunjukkan untuk setiap jenis ancaman di mana D (disengaja), A (tidak disengaja), E (lingkungan) 
adalah relevan. D digunakan untuk semua tindakan sengaja ditujukan untuk aset informasi, A digunakan untuk semua tindakan manusia yang tidak sengaja dapat merusak aset informasi, dan E digunakan untuk semua Insiden yang tidak didasarkan pada tindakan manusia. Kelompok-kelompok dari ancaman tidak dalam urutan prioritas. $\mathrm{i}$

\section{Tabel 4.2 Jenis Ancaman}

\begin{tabular}{|c|c|c|c|}
\hline $\begin{array}{l}\mathbf{N} \\
\mathbf{0}\end{array}$ & $\begin{array}{l}\text { Jeni } \\
\text { s }\end{array}$ & Ancaman & Asal \\
\hline \multirow[t]{3}{*}{1} & \multirow{3}{*}{ 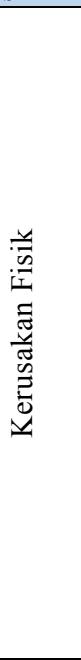 } & $\begin{array}{l}\text { Kecelakaan besar } \\
\text { A: Gempa bumi, banjir dan } \\
\text { rembesan air, dan kebakaran } \\
\text { D: Pelanggaran pemeliharaan } \\
\text { media fisik } \\
\text { E. pencurian hardware baik dari } \\
\text { dalam atau dari luar } \\
\end{array}$ & $\mathrm{A}, \mathrm{D}, \mathrm{E}$ \\
\hline & & $\begin{array}{l}\text { Perusakan pada peralatan atau } \\
\text { media } \\
\text { A: Kesalahan penyimpanan media } \\
\text { Fisik } \\
\text { D: Pelanggaran pemeliharaan } \\
\text { media fisik } \\
\text { E: Akses lebih dari satu pintu }\end{array}$ & $\mathrm{A}, \mathrm{D}, \mathrm{E}$ \\
\hline & & $\begin{array}{l}\text { Debu, korosi, pembekuan } \\
\text { A: Pentilasi Udara tidak otomatis } \\
\text { D: tidak ada alat pengatur suhu } \\
\text { E: suhu udara yang tidak stabil }\end{array}$ & $\mathrm{A}, \mathrm{D}, \mathrm{E}$ \\
\hline \multirow[t]{4}{*}{2} & \multirow{4}{*}{ 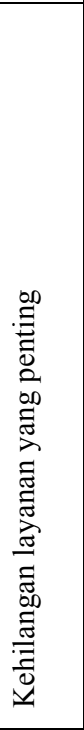 } & $\begin{array}{l}\text { Kegagalan AC } \\
\text { A: Listrik Down } \\
\text { B: Pemeliharaan Tidak rutin }\end{array}$ & A, D \\
\hline & & $\begin{array}{l}\text { Hilangnya pasokan listrik } \\
\text { A: Kesalahan intalasi pengkabelan } \\
\text { D: Ada pemadaman listrik dari } \\
\text { pusat } \\
\text { E: Pohon Tumbang Kena Kabel } \\
\text { Listrik }\end{array}$ & $\mathrm{A}, \mathrm{D}, \mathrm{E}$ \\
\hline & & $\begin{array}{l}\text { Kegagalan koneksi } \\
\text { A: Kerusakan kabel jaringan } \\
\text { D: Pelanggaran ketersediaan } \\
\text { personil } \\
\text { E: interfensi Sinyal, gangguan } \\
\quad \text { koneksi internet } \\
\end{array}$ & $\mathrm{A}, \mathrm{D}, \mathrm{E}$ \\
\hline & & $\begin{array}{l}\text { Kesalahan routing } \\
\text { kerusakan kabel jaringan } \\
\text { komputer atau kerusakan jaringan } \\
\text { wireless dan gangguan Koneksi } \\
\text { Internet }\end{array}$ & $\mathrm{A}$ \\
\hline \multirow[t]{3}{*}{3.} & \multirow[t]{3}{*}{ 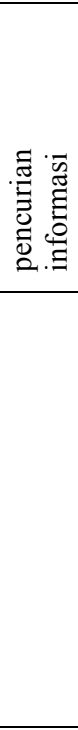 } & $\begin{array}{l}\text { Penyusupan pada saluran } \\
\text { komunikasi } \\
\text { penyadapan, interception (akses } \\
\text { data oleh user yang tidak berhak), } \\
\text { penyalahgunaan perangkat lunak, } \\
\text { spam, spyware,sql injection, } \\
\text { trozan horse, virus dan worm } \\
\text { sampai pada komputer error }\end{array}$ & $\mathrm{D}$ \\
\hline & & $\begin{array}{l}\text { Pencurian media atau dokumen } \\
\text { Dokumen hilang, pencurian } \\
\text { berkas dokumen, mengakses } \\
\text { perangkat bukan yang berhak, } \\
\text { menyalin aplikasi secara ilegal, } \\
\text { pemberitahuan akses login pada } \\
\text { orang lain, penyalahgunaan hak } \\
\text { akses }\end{array}$ & $\mathrm{D}$ \\
\hline & & $\begin{array}{l}\text { Pencurian peralatan } \\
\text { pencurian } \\
\text { telekomuniaksi atau jardware, } \\
\text { pintu akses tidak dikun }\end{array}$ & $\mathrm{D}$ \\
\hline
\end{tabular}

\begin{tabular}{|c|c|c|c|}
\hline & & $\begin{array}{l}\text { Data dari sumber yang tidak daat } \\
\text { dipercaya } \\
\text { A: Informasi di baca oleh pihak } \\
\text { yang tidak berwenang } \\
\text { D: input data palsu, pelanggaran } \\
\text { pemeliharaan sistem informasi, } \\
\text { penyebaran data rahasia dan } \\
\text { pengolahan data ilegal }\end{array}$ & $\mathrm{A}, \mathrm{D}$ \\
\hline & & $\begin{array}{l}\text { Gangguan perangkat keras } \\
\text { Kesalahan instalasi, hardware } \\
\text { rusak, sebagian periperal } \\
\text { komputer tidak berfungsi, } \\
\text { pemeliharaan perbaikan tidak } \\
\text { rutin, kesalahan personil, tidak ada } \\
\text { upgrade hardware, gangguan } \\
\text { listrik }\end{array}$ & D \\
\hline & & $\begin{array}{l}\text { Gangguan perangkat lunak } \\
\text { D: Kesalahan penggunaan } \\
\text { perangkat TI, kesalahan install } \\
\text { aplikasi, kesalahan penggunaan } \\
\text { aplikasi, penggunaan aplikasi } \\
\text { secara ilegal, penggunaan } \\
\text { perangkat lunak yang tidak } \\
\text { berhak, } \\
\text { A: sistem operasi error, DBMS } \\
\text { error }\end{array}$ & $\mathrm{A}, \mathrm{D}$ \\
\hline & & $\begin{array}{l}\text { Intersepsi mengorbankan } \\
\text { sinyal interferensi } \\
\text { Ancaman hacker dan cracker }\end{array}$ & D \\
\hline \multirow[t]{5}{*}{4} & \multirow{5}{*}{ 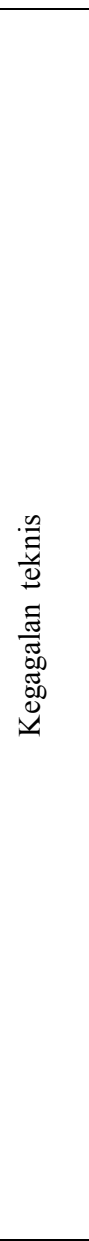 } & $\begin{array}{l}\text { Kegagalan peralatan } \\
\text { Kabel jaringan terkena korosi, } \\
\text { kabel putus, kabel tidak } \\
\text { memenuhi standar, tidak adanya } \\
\text { pelabelan.pemeliharaan yang } \\
\text { tidak teratur }\end{array}$ & A \\
\hline & & $\begin{array}{l}\text { Kerusakan peralatan } \\
\text { Instalasi pengakbelan terjadi } \\
\text { kerusakan karena digigit tikus, } \\
\text { hardware rusak karena kena } \\
\text { debu, air dan pembekuan }\end{array}$ & A \\
\hline & & $\begin{array}{l}\text { Kejenuhan sistem informasi } \\
\text { A: Sistem informasi error, } \\
\text { sistem operasi error, terjadinya } \\
\text { error antara DBMS dengan } \\
\text { aplikasi } \\
\text { D; tidak dibatasi hak akses } \\
\text { terhadap pengaksesan sistem } \\
\text { informasi }\end{array}$ & $A, D$ \\
\hline & & $\begin{array}{l}\text { Kerusakan perangkat lunak } \\
\text { Kesalahan penggunaan } \\
\text { perangkat lunak, install } \\
\text { perangkat lunak yang tidak } \\
\text { berhak, dan kesalahan } \\
\text { penggunaan perangkat lunak }\end{array}$ & A \\
\hline & & 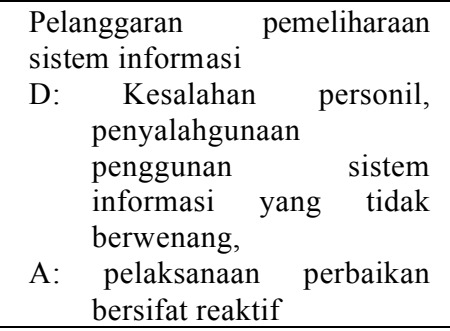 & A, D \\
\hline 5 & 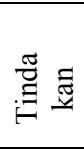 & $\begin{array}{llr}\text { Penggunaan peralatan } & \text { yang } \\
\text { tidak sah } & & \\
\text { Penggunaan bersama } & \text { karena } \\
\text { tidak ada pelabelan } & \\
\end{array}$ & $\mathrm{D}$ \\
\hline
\end{tabular}




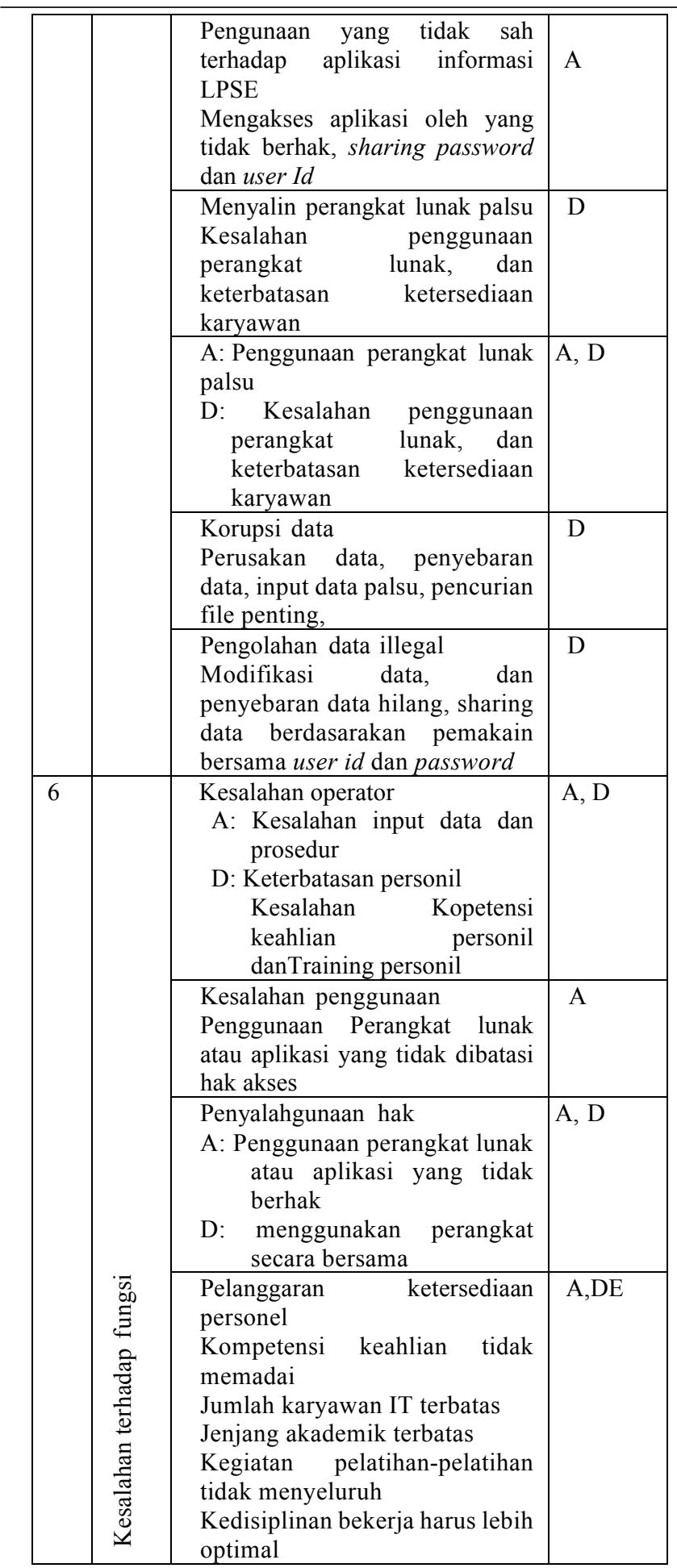

Untuk menentukan kriteria-kriteria jenis, ancaman dan sumber ancaman baik itu disengaja (D), tidak disengaja (A) dan lingkungan (E) (diambil dari SNI ISO/IEC 27005:2013).

\subsubsection{Kerentanan}

Tabel 4.4 adalah kerentanan dalam berbagai area keamanan, termasuk beberapa ancaman yang mungkin mengeksploitasi kerentanan itu. Daftar ini dapat memberikan bantuan selama penilaian ancaman dan kerentanan, untuk menentukan skenario insiden yang relevan.
Tabel 4.3 Kerentanan dan Ancaman

\begin{tabular}{|c|c|c|}
\hline Jenis & Kerentanan & Ancaman \\
\hline \multirow{5}{*}{ 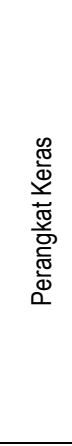 } & $\begin{array}{l}\text { Kurangnya } \\
\text { pemeliharaan/ } \\
\text { kesalahan instalasi } \\
\text { media penyimpanan }\end{array}$ & $\begin{array}{l}\text { Pelanggaran pemeliharaan } \\
\text { sistem informasi }\end{array}$ \\
\hline & $\begin{array}{l}\text { Kurangnya kontrol perubahan } \\
\text { konfigurasi yang efisien }\end{array}$ & Kesalahan penggunaan \\
\hline & $\begin{array}{l}\text { Kerentanan terhadap voltase } \\
\text { yang bervariasi }\end{array}$ & Hilangnya pasokan listrik \\
\hline & Penyimpanan yang tidak dilindungi & $\begin{array}{l}\text { Pencurian media atau } \\
\text { dokumen }\end{array}$ \\
\hline & Penyalinan yang tidak terkendali & $\begin{array}{l}\text { Pencurian media atau } \\
\text { dokumen }\end{array}$ \\
\hline \multirow{14}{*}{ 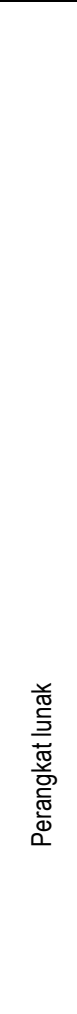 } & $\begin{array}{l}\text { Tidak ada pengujian } \\
\text { perangkat lunak }\end{array}$ & Penyalahgunaan hak \\
\hline & $\begin{array}{l}\text { Tidak 'logout' } \\
\text { meninggalkan komputer }\end{array}$ & Penyalahgunaan hak \\
\hline & Kesalahan penempatan hak akses & Penyalahgunaan hak \\
\hline & $\begin{array}{l}\text { Perangkat lunak yang } \\
\text { didistribusikan } \\
\text { luas }\end{array}$ & Korupsi data \\
\hline & $\begin{array}{l}\text { Menerapkan program aplikasi } \\
\text { untuk data yang salah dalam } \\
\text { hal waktu }\end{array}$ & Korupsi data \\
\hline & Antar muka yang rumit & Kesalahan penggunaan \\
\hline & Kurangnya dokumentasi & Kesalahan penggunaan \\
\hline & Kesalahan tanggal & Kesalahan penggunaan \\
\hline & $\begin{array}{l}\text { Kurangnya mekanisme identifikasi } \\
\text { dan otentikasi seperti otentikasi } \\
\text { pengguna }\end{array}$ & Pemalsuan hak \\
\hline & $\begin{array}{l}\text { Tabel password yang tidak } \\
\text { dilindungi }\end{array}$ & Pemalsuan hak \\
\hline & Manajemen password yang buruk & Pemalsuan hak \\
\hline & $\begin{array}{l}\text { Pengunduhan dan penggunaan } \\
\text { perangkat lunak yang tidak } \\
\text { terkontrol }\end{array}$ & $\begin{array}{ll}\text { Perusakan } & \text { dengan } \\
\text { perangkat lunak } & \end{array}$ \\
\hline & Kurangnya salinan back-up & $\begin{array}{l}\text { Perusakan dengan } \\
\text { perangkat lunak }\end{array}$ \\
\hline & $\begin{array}{l}\text { Kurangnya perlindungan fisik pada } \\
\text { gedung, pintu, dan jendela }\end{array}$ & $\begin{array}{l}\text { Pencurian media } \\
\text { atau dokumen }\end{array}$ \\
\hline \multirow{7}{*}{ 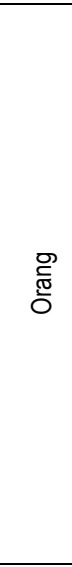 } & Ketidakhadiran personel & $\begin{array}{l}\text { Pelanggaran ketersediaan } \\
\text { personel }\end{array}$ \\
\hline & $\begin{array}{l}\text { Prosedur rekrutmen yang tidak } \\
\text { cukup }\end{array}$ & $\begin{array}{l}\text { Perusakan peralatan atau } \\
\text { media }\end{array}$ \\
\hline & $\begin{array}{l}\text { Pelatihan keamanan yang tidak } \\
\text { cukup }\end{array}$ & Kesalahan penggunaan \\
\hline & $\begin{array}{l}\text { Kesalahan penggunaan } \\
\text { atas perangkat lunak dan } \\
\text { perangkat keras }\end{array}$ & Kesalahan penggunaan \\
\hline & $\begin{array}{l}\text { Kurangnya kesadaran akan } \\
\text { keamanan }\end{array}$ & Kesalahan penggunaan \\
\hline & Kurangnya mekanisme pemantauan & Pengolahan data ilegal \\
\hline & $\begin{array}{l}\text { Bekerja tanpa pengawasan oleh } \\
\text { orang luar atau karyawan } \\
\text { pembersih }\end{array}$ & $\begin{array}{l}\text { Pencurian media } \\
\text { atau dokumen }\end{array}$ \\
\hline \multirow{3}{*}{ 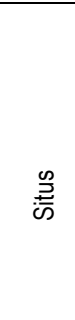 } & $\begin{array}{l}\text { Penggunaan yang tidak } \\
\text { memadai atau ceroboh } \\
\text { atas kontrol akses fisik ke } \\
\text { bangunan dan ruangan- } \\
\text { ruangan }\end{array}$ & $\begin{array}{l}\text { Perusakan peralatan atau } \\
\text { media }\end{array}$ \\
\hline & Jaringan listrik yang tidak stabil & Hilangnya pasokan listrik \\
\hline & $\begin{array}{l}\text { Kurangnya perlindungan } \\
\text { fisik terhadap gedung, } \\
\text { pintu, dan jendela }\end{array}$ & Pencurian peralatan \\
\hline
\end{tabular}


Fuad Nasher, Perancangan Sistem Manajemen Keamanan Informasi Layanan Pengadaan Barang/Jasa Secara Elektronik (LPSE)

\begin{tabular}{|c|c|c|}
\hline \multirow{16}{*}{ 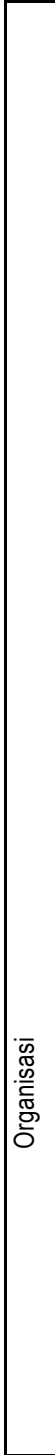 } & $\begin{array}{lr}\text { Kurangnya prosedur } & \text { formal } \\
\text { untuk pendaftaran } & \text { dan } \\
\text { penghapusan pengguna } & \\
\end{array}$ & Penyalahgunaan hak \\
\hline & $\begin{array}{l}\text { Kurangnya proses formal untuk } \\
\text { meninjau } \\
\text { (pengawasan) }\end{array}$ & Penyalahgunaan hak \\
\hline & $\begin{array}{ll}\text { Kurangnya } & \text { prosedur } \\
\text { pemantauan fasilitas } & \text { pengolah } \\
\text { informasi } & \end{array}$ & Penyalahgunaan hak \\
\hline & $\begin{array}{l}\text { Respon pemeliharaan layanan } \\
\text { yang tidak memadai }\end{array}$ & $\begin{array}{l}\text { Menerobos } \\
\text { pertahanan sistem }\end{array}$ \\
\hline & $\begin{array}{l}\text { Kurangnya proses formal } \\
\text { untuk meninjau hak akses } \\
\text { (pengawasan) }\end{array}$ & Penyalahgunaan hak \\
\hline & $\begin{array}{ll}\text { Kurangnya } & \text { prosedur } \\
\text { pemantauan fasilitas } & \text { pengolah } \\
\text { informasi } & \\
\end{array}$ & Penyalahgunaan hak \\
\hline & $\begin{array}{l}\text { Respon pemeliharaan layanan } \\
\text { yang tidak memadai }\end{array}$ & $\begin{array}{l}\text { Menerobos } \\
\text { pertahanan sistem }\end{array}$ \\
\hline & $\begin{array}{l}\text { Kurangnya proses formal } \\
\text { untuk otorisasi informasi yang } \\
\text { tersedia }\end{array}$ & $\begin{array}{lr}\text { Data dari } & \text { sumber } \\
\text { yang } & \text { tidak } \\
\text { terpercaya } & \\
\end{array}$ \\
\hline & $\begin{array}{lr}\text { Kurangnya } & \text { kebijakan } \\
\text { penggunaan } & \text { surat elektronik }\end{array}$ & Kesalahan penggunaan \\
\hline & $\begin{array}{l}\text { Kurangnya prosedur untuk } \\
\text { menangani informasi } \\
\text { rahasia }\end{array}$ & Kesalahan penggunaan \\
\hline & $\begin{array}{lll}\text { Kurangnya tanggung } & \text { jawab } \\
\text { keamanan informasi } & \text { dalam } \\
\text { deskripsi pekerjaan } & \\
\end{array}$ & Kesalahan penggunaan \\
\hline & $\begin{array}{lr}\text { Kurangnya } & \text { atau } \\
\text { memadainya } & \text { tidak } \\
\text { (mengenai } & \text { ketentuan } \\
\end{array}$ & Pengolahan data ilegal \\
\hline & $\begin{array}{l}\text { Kurangnya } \\
\text { kebijakan formal } \\
\text { pada penggunaan } \\
\text { nonsel }\end{array}$ & Pencurian peralatan \\
\hline & $\begin{array}{l}\text { Kurangnya penguasaan aset } \\
\text { lokal }\end{array}$ & Pencurian peralatan \\
\hline & $\begin{array}{l}\text { Kurangnya atau tidak cukup } \\
\text { kebijakan'meja bersih dan layar }\end{array}$ & $\begin{array}{l}\text { Pencurian media atau } \\
\text { dokumen }\end{array}$ \\
\hline & $\begin{array}{l}\text { Kurangnya otorisasi fasilitas } \\
\text { pengolahan informasi }\end{array}$ & $\begin{array}{l}\text { Pencurian media } \\
\text { atau dokumen }\end{array}$ \\
\hline
\end{tabular}

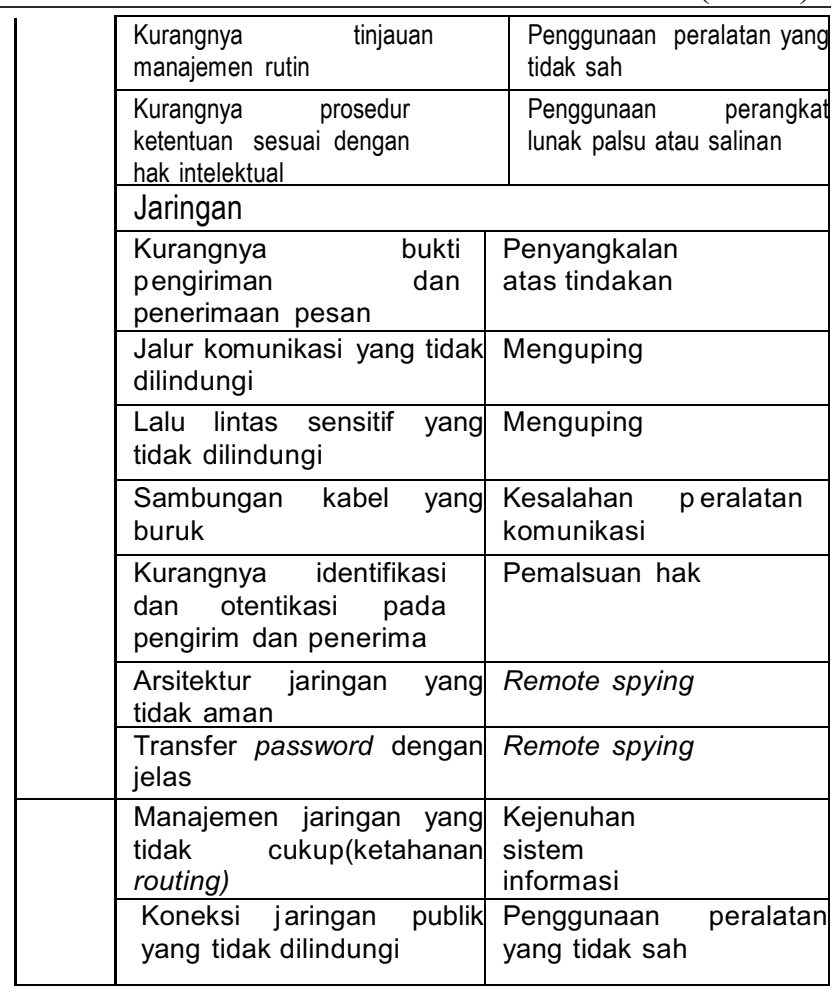

\subsubsection{Analisis Kemungkinan, Dampak, Penilaian Risiko dan Pengendalian}

Setelah dilakukannya tahapan identifikasi risiko berdasarkan kritikalitas pada aset dengan Selanjutnya dilakukan analisa risiko aset berdasarkan kriteria ancaman (Threat), kerawanan (Vulnerability) dan dampak (Effect). Selanjutnya dilakukan penilaian risiko dan pengendalian berdasarkan Hasil dari nilai risiko di tunjukkan pada tabel 4.5.sebagai berikut:

Tabel 4.5 Penilaian Resiko dan pengendalian

\begin{tabular}{|c|c|c|c|c|c|c|c|c|c|}
\hline $\begin{array}{r}\text { Nama } \\
\text { Aset }\end{array}$ & Kerentanan & Ancaman & Dampak & Pengendalian & $\begin{array}{l}\text { Nilai } \\
\text { aset }\end{array}$ & $\begin{array}{c}\text { Nilai } \\
\text { dampak }\end{array}$ & $\begin{array}{c}\text { Nilai } \\
\text { kemungkin } \\
\text { an }\end{array}$ & $\begin{array}{l}\text { Nilai } \\
\text { resiko }\end{array}$ & $\begin{array}{c}\text { keterang } \\
\text { an }\end{array}$ \\
\hline $\begin{array}{l}\text { Jaringan } \\
\text { Fax } \\
\text { dan } \\
\text { jaringan } \\
\text { telephone }\end{array}$ & $\begin{array}{lr}\text { Belum terlasana } \\
\text { dengan optimal } \\
\text { dalam } & \\
\text { pengelolaan } & \\
\text { keamanan } & \text { dan } \\
\text { akses } & \text { fisik } \\
\text { ruangan } & \\
\end{array}$ & $\begin{array}{l}\text { Dapat diakses } \\
\text { oleh yang tidak } \\
\text { berhak }\end{array}$ & $\begin{array}{ll}\text { Kebutuhan } & \text { akan } \\
\text { pengadaan } & \\
\text { terganggu } & \end{array}$ & $\begin{array}{l}\text { Pembatas fisik dan } \\
\text { kunci }\end{array}$ & 3 & 2 & 2 & 5 & Kontrol \\
\hline & \multicolumn{8}{|c|}{ Dan seterusnya } & \\
\hline
\end{tabular}

Setelah menentukan nilai penilaian resiko dan pengendalian selanjutnya dilakukan perhitungan penilaian risiko akhir. Penghitungan nilai risiko, kemudian hasil dari penilaian tersebut akan dibagi kedalam beberapa tingkatan kategori antara lain kategori rendah, sedang dan tinggi. Masing-masing tingkatan juga akan memiliki nilai yang tersendiri antara lain :

$\begin{array}{ll}\text { Rendah } & : 0-2 \\ \text { Sedang } & : 3-5 \\ \text { Tinggi } & : 6-8\end{array}$

(sumber SNI ISO/IEC 27005:2013)
Dengan tabel 4.5 ditunjukan dari 6 kategori aset memiliki penilaian risiko akhir $3-6$ berarti termasuk pada resiko sedang dan tinggi.

\subsubsection{Evaluasi Control Objective and Control}

berikut hasil evaluasi berdasarkan kuesioner Control Objective \& Control yang sesuai dengan rencana perancangan SMKI di LPSE Dinas Komunikasi dan Informatika Kabupaten Cianjur. Adapun pihak-pihak yang menilai evaluasi tersebut yaitu Sekretaris Kepala Unit LPSE, Kepala Bidang unit Administrasi sistem informasi, dan Kepala Bidang unit layanan

Berikut nilai evaluasi berdasarkan Klausul-Klausul SNI ISO/IEC 2700: 2013: 
1. Nilai evaluasi Klausul Sumber daya manausia

Nilai evaluasi ketersedian dokumen berdasarkan hasil kuesioner nilai rata-ratanya adalah 1,8 berarti berada pada kategori rendah, dan berdasarkan pertanyaan di tabel 4.5 bahwa secara keseluruhan Dokumen standar kompetensi bagi SDM keamanan informasi masih belum tersedia tapi secara teknis sudah diterapkan.

\section{Nilai Evaluasi Klausul A.9 Akses Kontrol}

Nilai evaluasi ketersedian dokumen berdasarkan hasil kuesioner nilai rata-ratanya adalah 2.3 berarti berada pada kategori rendah. hasil kuesioner ini sudah ada beberapa SOP yang tersedia seperti Dokumen log perubahan sistem informasi dan upaya akses yang tidak pantas, ada aturan-aturan yang sudah diterapakan.

\section{Nilai evaluasi Klausul A Keamanan aset}

ketersedian dokumen berdasarkan hasil kuesioner nilai rata-ratanya adalah 1,9 berarti berada pada kategori rendah, bahwa pada saat ini Dokumen daftar inventaris asset informasi dan aset TI ada beberapa yang tersedia, pada dokumen klasifikasi aset, tingkat ancaman, dan dampak kerugian keamanan informasi belum tersedia,dokumen syarat serta prosedur penghancuran data dan pertukaran data dengan pihak eksternal belum tersedia.

4. Nilai Evaluasi Kalusul A Keamanan Fisik dan Lingkungan

Nilai Evaluasi ketersedian dokumen berdasarkan hasil kuesioner nilai rata-ratanya adalah 2.5

berarti berada pada kategori rendah, hasil kuesioner ini sudah ada beberapa SOP yang tersedia seperti kontrol masuk pihak ketiga, keamanan pengkabelan, dan pemeliharaan peralatan secara keseluruhan Dokumen pengelolaan fasilitas fisik/ lokasi kerja belum tersedia.

5. Nilai Evaluasi Kalusul A.13 Keamanan Komunikasi

Nilai evaluasi ketersedian dokumen berdasarkan hasil kuesioner nilai rata-ratanya adalah 2.9 berarti berada pada kategori rendah secara teknis konsep-konsep tentang keamanan sudah diterapakan, namun belum tersedia dokumen seperti Tata tertib penggunaan komputer, email, inetrnet, dan intranet. Dokumen Tata tertib penggunaan dan pengaman aset

Berdasarakan hasil evaluasi dari 5 Klausul maka nilai rata-rata nya adalah 2.3. maka dapat disimpulkan bahwa sistem pengamanan informasi di LPSE dinas Komunikasi dan Informatika Kabupaten Cianjur termasuk kategori rendah.

\section{a. Analisa Kesenjangan (Gap Analysis)}

Sebelum melakukan pemetaan rekomendasi yang dipilih dari SNI ISO/IEC 27001: 2013 terlebih dahulu melakukan analisa kesenjangan yaitu bagimana mengidentifikasi apakah sistem saat ini telah memenuhi kebutuhan. Maka Pada tahap ini melakukan requrement dari LPSE, menetukan penyesuaian yang diperlukan dan memastikan dengan sistem yang baru memenuhi kebutuhan bisnis yang memastikan menjadi best practice, dan mengidentifikasi permaslahan yang membutuhkan perubahan kebijakan di perusahaan. Menurut narasumber bahwa ada alasan yang menjadi kendala dalam penyusunan yaitu :
1. Adanya migrasi kedinasan dari dinas Perhubungan ke dinas Komunikasi dan Informatika dimana unit LPSE pada awalnya berada dibawah Dishub sekarang dibawah Dinas Kominfo sehingga harus menyesuaikan dengan pola kerja dan kebijakan yang baru.

2. Sumber daya manusia memiliki 7 karyawan terdiri dari 2 karyawan tetap (PNS), 2 karyawan tetap bukan PNS, dan 3 karyawan tidak tetap (honorer). Dengan keterbatasan sumber daya ini menjadi kendala untuk pencapaian dalam perumusan Sistem Manajemen Keamanan Informasi secara maksimal dan oftimal.

Berikut akan ditampilkan analisis kesenjangan LPSE di dinas Kominfo Kabupaten Cianjur antara lain

1. Gap Analysis Tata Kelola Kemanan Informasi

a. Kurangnya jumlah SDM yang menangani pengelolaan keamanan informasi dan belum ada pembagian wewenang

b. Tidak adanya standar untuk patokan minimum kompetensi dan keahlian dari staff pengelolaan keamanan informasi

c. Program peningkatan kompetensi yang dilakukan untuk staff pengelolaan keamanan informasi masih belum merata

d. Tidak adanya dokumen koordinasi dengan pihak pengguna internal dan eksternal

e. Tidak adanya standar terkait pengamanan informasi yang harus dipatuhi

2. Gap Analysis tentang pengelolaan risiko

a. Tidak adanya program kerja terkait pengelolaan risiko keamanan informasi

b. Tidak adanya bagian khusus yang bertanggung jawa menangani pengelolaan risiko keamanan informasi

c. Tidak adanya kerangka kerja yang digunakan terkait pengelolaan risiko keamanan informasi, seperti standar ISO 27001:2013

d. Tidak adanya dokumentasi keterhubungan klasifikasi aset informasi, tingkat ancaman, dan dampak yang dihasilkan dari terjadinya risiko keamanan informasi

3. Gap Analysis Kerangka Kerja

a. Belum ada mekanisme dalam pengelolaan distribusi, penyimpanan, dan penarikan dari peredaran terkait kebijakan dan prosedur keamanan informasi

b. Belum adanya proses pengkomunikasian kebijakan keamanan informasi serta perubahannya pada pihak ketiga

c. Tidak adanya kegiatan audit internal yang terdiri dari rencana audit, audit program, evaluasi hasil.

\section{Gap Analysis Aset}

a. Tidak adanya peraturan perundang-undangan yang digunakan LPSE terkait klasifikasi aset informasi dan evaluasinya

b. Tidak adanya mekanisme pengamanan fisik dalam pengiriman aset informasi dengan pihak ketiga

c. Tidak adanya peraturan resmi untuk pengamanan ruang server dan ruang arsip dari ancaman aset informasi, seperti larangan penggunaan handphone, larangan penggunaan kamera dan lain-lain

d. Tidak adanya tata tertib terkait penggunaan komputer, email, internet, intranet, dan pengamanan aset.

e. Tidak adanya peraturan terhadap penggunaan data pribadi 
f. Tidak adanya kebijakan terhadap pelanggaran dari pengelolaan identitas serta proses otentikasi (username \& password)

g. Tidak adanya prosedur dan syarat terkait pemberian akses, otentikasi, dan otorisasi untuk penggunaan aset informasi

h. Tidak adanya prosedur untuk mutasi user atau tenaga kontrak yang habis masa kerjanya

5. Gap Analysis Teknologi

a. Tidak dilakukannya pemindaian jaringan, sistem, dan aplikasi secara rutin. Jaringan, sistem, dan aplikasi akan dipindai hanya jika ada insiden yang terjadi

b. Tidak digunakannya standar untuk penerapan enkripsi

Tabel 4.6 Pemetaan klausul SNI ISO/IEC 27001:2013

\begin{tabular}{|c|c|c|c|c|c|c|c|}
\hline Nama aset & Kerentanan & Ancaman & dampak & $\begin{array}{l}\text { Pengendalian } \\
\text { saat ini }\end{array}$ & $\begin{array}{l}\text { Nilai } \\
\text { resiko }\end{array}$ & $\begin{array}{c}\text { SNI ISO/IEC } \\
27001: 2013\end{array}$ & $\begin{array}{l}\text { Peraturan dan } \\
\text { Prosedur }\end{array}$ \\
\hline $\begin{array}{l}\text { Jaringan } \\
\text { Fax } \\
\text { dan } \\
\text { jaringan } \\
\text { telephone }\end{array}$ & $\begin{array}{l}\text { Belum terlasana } \\
\text { dengan optimal } \\
\text { dalam } \\
\text { pengelolaan } \\
\text { keamanan dan } \\
\text { akses } \\
\text { ruangan }\end{array}$ & $\begin{array}{l}\text { Dapat } \\
\text { diakses } \\
\text { oleh yang } \\
\text { tidak } \\
\text { berhak }\end{array}$ & $\begin{array}{l}\text { Kebutuhan } \\
\text { akan } \\
\text { pengadaan } \\
\text { terganggu }\end{array}$ & $\begin{array}{l}\text { Pembatas } \\
\text { fisik dan } \\
\text { kunci }\end{array}$ & 5 & $\begin{array}{l}\text { A.11.1.3 } \\
\text { securing } \\
\text { officersw, } \\
\text { rooms and } \\
\text { pacilities } \\
\text { A.11.1.5 } \\
\text { working in } \\
\text { secure areas }\end{array}$ & $\begin{array}{c}\text { Peraturan tentang } \\
\text { pengamanan fisik } \\
\text { Prosedure bekerja } \\
\text { di wilayah aman }\end{array}$ \\
\hline
\end{tabular}

Hasil dari pemetaan kontrol dengan kerangka kerja SNI ISO/IEC 27001:2013 maka yang perlu dirancang SMKI berdasarkan penelitian yang dilakukan pemetaan tersebut terdapat 21 klausul yang digunakan yaitu sebagai berikut :

Tabel 4.15 Pemetaan Kontrol SNI ISO/IEC 27001:2013

\begin{tabular}{|c|c|c|}
\hline \multicolumn{2}{|r|}{ Klausul S N I ISO/IEC 27001:2013 } & Kontrol \\
\hline 1. & Seleksi pegawai & A.7.1.1 \\
\hline 2. & Persyaratan SDM & A.7.1.2 \\
\hline 3. & $\begin{array}{l}\text { Pendidikan dan pelatihan keamanan } \\
\text { informasi }\end{array}$ & A.7.2.2 \\
\hline 4. & Kedisiplinan & A 7.2 .3 . \\
\hline 5. & Penanganan aset & A.8.2.3 \\
\hline 6. & Aturan akses kontrol & A.9.1.1 \\
\hline 7. & Penyediaan akses pengguna & A.9.2.2 \\
\hline 8. & Pengelolaan hak akses istimewa & A.9.2.3 \\
\hline 9. & $\begin{array}{l}\text { Pengelolaan informasi otentikasi } \\
\text { rahasia pengguna }\end{array}$ & A.9.2.4 \\
\hline 10. & Review hak akses pengguna & A.9.2.5 \\
\hline & $\begin{array}{l}\text { Pembatasan akses terhadap } \\
\text { informasi }\end{array}$ & A.9.4.1 \\
\hline 12. & Pengamanan prosedure log on & A.9.4.2 \\
\hline 13. & Sistem pengaturan password & A.9.4.3 \\
\hline & $\begin{array}{l}\text { Penggunaan program Utilitas } \\
\text { istimewa }\end{array}$ & A.9.4.4 \\
\hline 15. & Klasifikasi aset & A.8.2.1 \\
\hline 16. & $\begin{array}{l}\text { Perlindungan dari bencana } \\
\text { alam,serangan dari luar }\end{array}$ & A.11.1.4 \\
\hline & $\begin{array}{l}\text { Penempatan peralatan di wilayah } \\
\text { aman }\end{array}$ & A.11.2.1 \\
\hline 18. & Utilitas pendukung & A.11.2.2 \\
\hline & Keamanan pengkabelan & A.11.2.3 \\
\hline & Pemeliharaan peralatan & A.11.2.4 \\
\hline 21. & $\begin{array}{l}\text { Kerahasiaan pertukaran informasi } \\
\text { (komunikasi) }\end{array}$ & A.13.2.4 \\
\hline
\end{tabular}

c. sistem aplikasi yang digunakan untuk mengganti password oleh user secara berkala

d. Tidak adanya rekaman hasil analisa yang berisi bahwa antivirus telah diupdate secara berkala dan tidak ada laporan tentang penyerangan virus yang berhasil ditindaklanjuti

b. Pemetaan Klausul SNI ISO/IEC 27001:2013

Setelah dilakukan penilaian risiko, evaluasi nilai Control Objective and Control SNI ISO/IEC 27001:2013 dan gap analisis maka selanjutnya melakukan rencana pemetaan kontrol dengan kerangka kerja SNI ISO/IEC 27001:2013 yaitu terdapat pada tabel 4.6
Adapun perancangan dokumen yang telah disusun berdasarkan pemetaan dengan SNI ISO/IEC 27001:2013 diatas terdiri dari:

1. Perancangan Manual Kebijakan SMKI

2. Perancangan SOP dan

3. Perancangan Formulir

\section{Kesimpulan dan Saran}

\subsection{Kesimpulan}

Kesimpulan dari hasil penelitian ini adalah telah dibuat perancangan Sistem Manajemen keamanan Informasi pada sistem Pengadaan Barang/jasa secara elektronik (LPSE) di Dinas Komunikasi dan Informatika Kabupaten Cianjur berdasarkan pemetaan kontrol dengan kerangka kerja SNI ISO/IEC 27001:2013 yaitu:

1. Terdapat 21 klausul yang digunakan dimana hasil rancangannya adalah Dokumen Manual Keamanan Informasi, Prosedur dan Formulir Sistem Manajemen Keamanan informasi. Dengan memiliki dokumen ini, sistem LPSE yang terdapat pada Dinas Komunikasi dan Informatika Kabupaten Cianjur diharapakan mendapatkan keterjaminan confidentiality, integrity dan availability dalam menjaga keamanan informasi serta meminimalisir terjadinya insiden atau risiko yang terdapat pada LPSE yang sangat tinggi.

2. Memberikan gambaran, referensi bagaimana merancang/membangun terkait dengan sistem manajemen keamanan informasi dalam melakukan perbaikan-perbaikan untuk menjamin terhadap keamanan informasi dan peningkatan kualitas. 


\subsection{Saran}

Hasil dari penelitian ini memerlukan pengembangan yang lebih lanjut. Salah satu dalam pembuatan dokumen SMKI pemetaan terhadap SNI ISO/IEC 207001: 2013 hanya 5 Klausul dari 14 Klausul dan beberapa kontrol klausul yang diterapakan sehingga masih banyak harus diperhatikan dan dibuatkan dokumen SMKI secara menyeluruh sehingga untuk rekomendasi untuk mendapatkan sertifikasi implementasi SMKI baik kesempatanya lebih tinggi. Dengan memiliki Information system management system certification maka peningkatan kepercayaan konsumen baik tingkat Nasional maupun Internasional semakin tinggi.

\section{Daftar Pustaka}

[1] Herbert, J., \& Mattord, M. (2004). Principles of Information security. NewYork: Course Technology Ptr.

[2] Kadir, A., \& Triwahyuni, T. C. (2003). Pengenalan Teknologi Informasi. Yogyakarta: Penerbit Andi.

[3] Ladjamudin, A.-B. B. (2005). Analisis dan Desain Sistem Informasi. Yogyakarta: Graha Ilmu.

[4] Sarno, R., \& Iffano, I. (2009). Sistem Manajemen Keamanan Informasi. Surabaya: ITS Press.

[5] Sugiono. ( 2013) Metode Penelitian Kombinasi: Bandung :penerbit Alpabeta

[6] IBISA.(2011). Keamanan Sistem Informasi. Yogyakarta : Penerbit Andi

[7] Jogiayanto , \& Abdillah, W. (2011). Sistem Tata Kelola Teknologi Informasi. Yogyakarta : Penerbit Andi

[8] Rafiandi,A, \& Cahyono,H.M (2010). Jurus Sukses Sertifikasi ISO 27001. Jakarta: Penebit PT Gramedia.

[9] Aprian.R.Rijal,S, Sobri,M.(2015) Perencanaan Sistem Manajemen Keamanan Informasi Menggunakan Standar ISO 27001:2013, Palembang

[10] Cheristian,I, Fathoni,Negara,S,E Perencanaan dan Implementasi Standar ISO 27001:2013 ( studi kasus PT. Sinar Sosro Palembang

[11] Basyarahil,A,F. (2017) Evaluasi Manajemen Keamanan Informasi Menggunakan Indek KAMI berdasarkan ISO 27001:2013 (studi kasus DPTSI ITS Surabaya

[12] Noveka,E.T.A, cahyani,D,N \& firdaus Y (2012) Perancangan Sistem Manajemen Keamanan Informasi Menggunakan ISO 27001 (Studi Kasus IT Telkom. Bandung

[13] Ritzkal, Georitno,A, Hendrawan,A,H () Implementasi ISO 27001:2013 Untuk SMKI (studi kasus Fakultas Teknik UIKA), Bogor

[14] Rakerna LPSE (2015) sistem manajemen Keamanan Informasi dan Pengelolaan Resiko, propinsi Jawa barat

[15] Laukka, L (2015) Information Security management System Implementation For A Cert, Tampare university of Technology.

[16] Nakrem,A.(2007) Managing Information Security in organizations, Agner University Colegge
[17] Satria.I.F Y, (2016 ) Gunadhi.E.RD, Risk Assessment pada manajemen risiko keamanan informasi mengacu pada British Standar ISO/IEC 207005 Risk Assessment, Sekolah Tinggi Teknologi Garut

[18] SNI ISO/IEC 27001:2013,IDT (2014) Teknologi Informasi-teknik Keamanan Sistem Manajemen Keamanan Informasi-persyaratan. BSN

[19] SNI ISO/IEC 27005:2011,IDT (2013)Teknologi Informasi-teknik Keamanan Manajemen Resiko Keamanan Informasi. BSN

[20] LPSE. (2015) Kajian Akademis, Pemerintah kabupaten Cianjur http://LPSE.cianjurkab.go.id

[21] KOMINFO RI (2012) Pemeringkatan e-government Indonesia kabupaten Kota wilayah Jawa Barat

[22] Undang Undang nomor 19 tahun 2016 undangundang atas perubahan Undang-undang no 11 tahun 2008 tentang informasi transaksi elektronik

[23] Peraturan Pemerintah Republik Indonesia no 82 tahun 2012 tentang penyelenggaraan sistem dan dan transaksi elektronik.

[24] Peraturan Menteri Komunikasi dan Informatika no 4 tahun 2016 tentang sistem manajemen Keamanan Informasi

[25] Perbub Cianjur no 29 tahun 2011 tentang pembentukan, organisasi dan tata kerja unit layanan pengadaan secara eletronik

[26] https://lpse.lkpp.go.id/eproc/ Layanan Pengadaan Secara Elektronik (LPSE)

[27] http://www.lkpp.go.id. Lembaga Kebijakan Pengadaan Barang/Jasa Pemerintah ( LKPP) 